\title{
BAT USE OF HIGHWAY BRIDGES IN SOUTH-CENTRAL MONTANA
}

FHWA/MT-05-007/8159

Final Report

prepared for

THE STATE OF MONTANA

DEPARTMENT OF TRANSPORTATION

in cooperation with

THE U.S. DEPARTMENT OF TRANSPORTATION

FEDERAL HIGHWAY ADMINISTRATION

August 2005

prepared by

Montana Natural Heritage Program

Paul Hendricks

Susan Lenard

Coburn Currier

Joseph Johnson

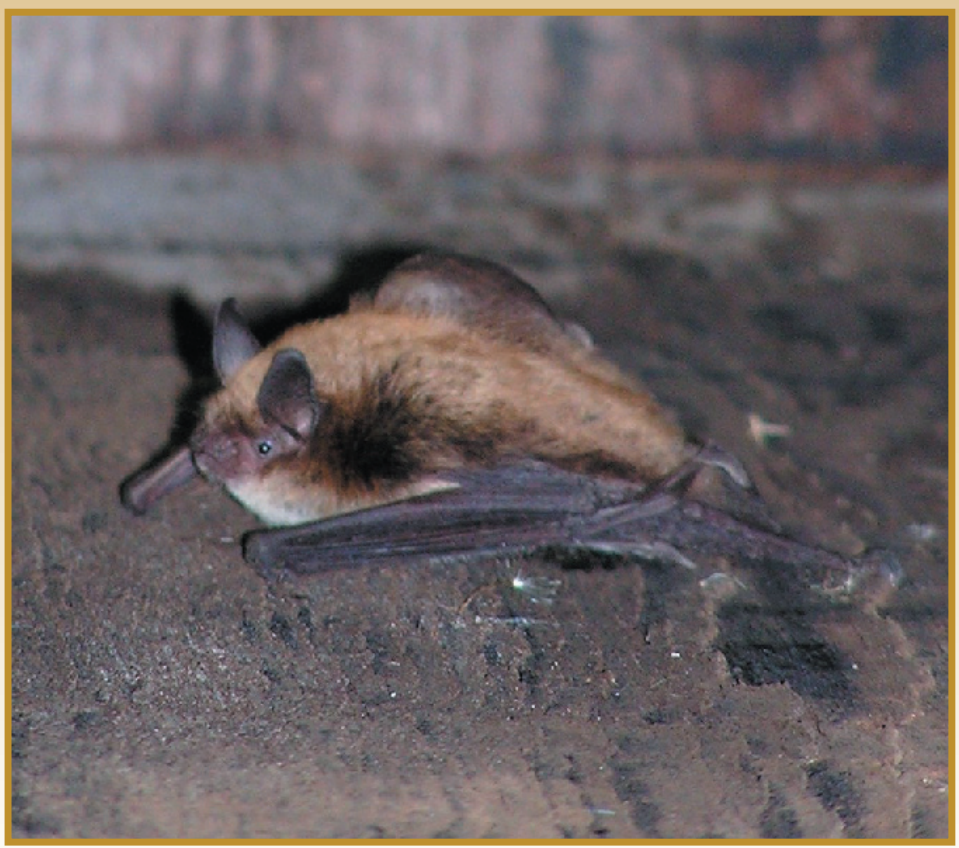

RESEARCH PROGRAMS 
You are free to copy, distribute, display, and perform the work; make derivative works; make commercial use of the work under the condition that you give the original author and sponsor credit. For any reuse or distribution, you must make clear to others the license terms of this work. Any of these conditions can be waived if you get permission from the sponsor. Your fair use and other rights are in no way affected by the above. 


\title{
BAT USE OF HIGHWAY BRIDGES IN SOUTH-CENTRAL MONTANA
}

\author{
A Report prepared for: \\ Montana Department of Transportation \\ Research Programs \\ 2701 Prospect Avenue \\ Helena, MT 59620 \\ in cooperation with the \\ U.S. DEPARTMENT OF TRANSPORTATION \\ FEDERAL HIGHWAY ADMINISTRATION
}

MDT Project \#8159

CFDA No. 20.205

\author{
Submitted by: \\ Paul Hendricks, Susan Lenard, Coburn Currier, and Joseph Johnson \\ Montana Natural Heritage Program \\ Natural Resources Information System \\ Montana State Library \\ P.O. Box 201800 \\ 1515 East Sixth Avenue \\ Helena, MT 59620-1800
}

June 2005 
TECHNICAL REPORT DOCUMENTATION PAGE

\begin{tabular}{|c|c|c|c|}
\hline \multicolumn{2}{|c|}{ 1. Report No. FHWA/MT-05-007/8159 } & 2. Government & 3. Recipient's Catalog No. \\
\hline \multirow{2}{*}{\multicolumn{2}{|c|}{$\begin{array}{l}\text { 4. Title and Subtitle } \\
\text { Bat Use of Highway Bridges in South-Central Montana }\end{array}$}} & \multicolumn{2}{|c|}{ 5. Report Date June 2005} \\
\hline & & \multicolumn{2}{|c|}{ 6. Performing Organization Code } \\
\hline \multicolumn{2}{|c|}{$\begin{array}{l}\text { 7. Author(s) } \\
\text { Paul Hendricks, Susan Lenard, Coburn Currier, and } \\
\text { Joseph Johnson }\end{array}$} & \multicolumn{2}{|c|}{ 8. Performing Organization Report No. } \\
\hline \multirow{2}{*}{\multicolumn{2}{|c|}{$\begin{array}{l}\text { 9. Performing Organization Name and Address } \\
\text { Montana Natural Heritage Program } \\
\text { Natural Resources Information System } \\
\text { Montana State Library } \\
\text { P.O. Box } 201800 \\
\text { 1515 East Sixth Avenue } \\
\text { Helena, MT 59620-1800 }\end{array}$}} & \multicolumn{2}{|c|}{ 10. Work Unit No. } \\
\hline & & \multicolumn{2}{|c|}{ 11. Contract or Grant No. 8159} \\
\hline \multirow{2}{*}{\multicolumn{2}{|c|}{$\begin{array}{l}\text { 12. Sponsoring Agency Name and Address } \\
\text { Research Programs } \\
\text { Montana Department of Transportation } \\
2701 \text { Prospect Avenue } \\
\text { PO Box } 201001 \\
\text { Helena MT } 59620-1001\end{array}$}} & \multicolumn{2}{|c|}{$\begin{array}{l}\text { 13. Type of Report and Period Covered } \\
\text { Final Report } \\
\text { June 2002-May } 2005\end{array}$} \\
\hline & & \multicolumn{2}{|c|}{ 14. Sponsoring Agency Code $\quad 5401$} \\
\hline \multicolumn{4}{|c|}{$\begin{array}{l}\text { 15. Supplementary Notes Research performed in cooperation with the Montana Department of Transportation and } \\
\text { the US Department of Transportation, Federal Highway Administration. }\end{array}$} \\
\hline \multicolumn{4}{|c|}{$\begin{array}{l}\text { 16. Abstract We studied use of highway structures by bats in the Billings, Montana area during } 2003 \text { and } 2004 \text {. We found } \\
\text { evidence of bat use at } 78 \text { of } 130 \text { highway structures examined during summer } 2003 \text { in Carbon, Stillwater, and Yellowstone } \\
\text { counties; } 66 \text { structures were used apparently exclusively for night roosting, and } 12 \text { bridges were day roosts. Use of } \\
\text { highway structures was widespread throughout the study area and among the state highway system categories } \\
\text { (Interstate: } 73.2 \% \text {, Primary: } 47.2 \% \text {, Secondary: } 57.1 \% \text {, Local/State Maintained: } 60.0 \% \text { ). Day roosts were found in all } \\
\text { highway system categories, but relatively more were in the Local/State Maintained category; maternity colonies were in all } \\
\text { but the Interstate category. } \\
\text { Bat species identified at day roosts included Big Brown Bat (Eptesicus fuscus), Hoary Bat (Lasiurus cinereus), Little } \\
\text { Brown Myotis (Myotis lucifugus), and Western Small-footed Myotis (M. ciliolabrum), none of which is a state Animal } \\
\text { Species of Concern; use of a bridge for day-roosting by the Hoary Bat is apparently the first documented case for this } \\
\text { species. Day roosts occupied in } 2003 \text { and } 2004 \text { included maternity colonies of Big Brown Bat (2) and Little Brown Myotis } \\
\text { (2). }\end{array}$} \\
\hline \multirow{2}{*}{\multicolumn{4}{|c|}{$\begin{array}{l}\text { Use of bridges for roosting, and intensity of use at night roosts, were generally unrelated to the landscape within } 3 \mathrm{~km} \\
\text { (1.86 miles) of the structure. Only mean percent of forest cover was significantly greater around day roost structures, but } \\
\text { substantial overlap among unused, night roost, and day roost categories indicated that this pattern was a trend and not } \\
\text { the major influence on structure use by bats. All day roosts were found within } 8 \mathrm{~km} \text { (5 miles) of riparian corridors. } \\
\text { Bats used } 75.9 \% \text { of concrete structures, } 37.5 \% \text { of steel structures, and } 31.6 \% \text { of wooden ones. Day roosts were found in } \\
\text { concrete or wood structures, none in steel; three maternity colonies were in wood bridges, one in a concrete bridge. Slab } \\
\text { bridges were the least preferred concrete spans because they provided few if any protected sites for roosting bats on the } \\
\text { underside of the deck. Night roosting bats perched on the exposed vertical surfaces of girders of concrete and steel } \\
\text { bridges. Day roosting sites in concrete bridges included accessible expansion joints between cast-in-place and T-beam } \\
\text { bridge sections, the longitudinal slots on the underdeck of parallel box-beam structures, and the space between two } \\
\text { abutting bridge lanes. Day roosts in wood bridges included the narrow space between parallel girders, and the spaces } \\
\text { between wood supports under the deck where railing posts were anchored. Of the } 12 \text { day-roosts found in } 2003 \text {, nine, } \\
\text { including all maternity colonies, were occupied on at least one visit in } 2004 \text {. Maternity colonies were occupied from early } \\
\text { June (possibly late May) into September, but dispersal from them had begun by late August. }\end{array}$}} \\
\hline & & & \\
\hline \multicolumn{2}{|c|}{$\begin{array}{l}\text { 17. Key Words } \\
\text { Bats, Bridge use, Montana, Roosts }\end{array}$} & \multicolumn{2}{|c|}{$\begin{array}{l}\text { 18. Distribution Statement } \\
\text { Unrestricted. This document is available through } \\
\text { the National Technical Information Service, } \\
\text { Springfield, VA } 21161 .\end{array}$} \\
\hline $\begin{array}{l}\text { 19. Security Classif. (of this report) } \\
\text { Unclassified }\end{array}$ & $\begin{array}{l}\text { 20. Security Classif. (of this page) } \\
\text { Unclassified }\end{array}$ & $\begin{array}{l}\text { 21. No. of Page } \\
\text { vi+31 }\end{array}$ & 22. Price \\
\hline
\end{tabular}




\section{ABSTRACT}

We studied use of highway structures by bats in the Billings, Montana area during 2003 and 2004. In summer 2003 we inspected 130 highway structures (125 bridges, five culverts) in three counties for evidence of use by bats. Of these, 15 structures were located in Carbon County, 45 in Stillwater County, and 70 in Yellowstone County. They were distributed among the Montana Department of Transportation Highway System as follows: 41 Interstate System structures, 36 Primary System structures, 28 Secondary System structures, and 25 Local/State Maintained System structures.

Use of bridges by roosting bats was widespread in this part of Montana. We found evidence of bat use at 78 structures (60.0\%); 66 structures (65 bridges, one culvert) apparently were used exclusively for night roosting (nocturnal rest sites for digesting meals in a protected location), and 12 bridges were day roosts (sites protected from weather and predators for raising young and/or sleeping during the day). Bats used structures relatively evenly among highway system categories (47.2\% of Primary System structures examined to $73.2 \%$ of Interstate System structures). Day roosts were found in $20 \%$ of the Local/State Maintained structures inspected, as compared to $5.6-7.3 \%$ of structures in other parts of the state highway system.

Four species of bats were identified in 2003 using highway structures for day roosting: Big Brown Bat (Eptesicus fuscus) in ten structures, Hoary Bat (Lasiurus cinereus) in one, Little Brown Myotis (Myotis lucifugus) in two, and Western Small-footed Myotis (M. ciliolabrum) in two. Big Brown Bat and Little Brown Myotis were the only species noted in 2004. None of these bats is a Montana Animal Species of Concern. Occupancy of day roosts was typically at least one month in duration, and at least three months (June-August) at maternity colonies.

Use of bridges by bats was generally unrelated to the surrounding landscape (agriculture, aquatic/wetland, commercial/urban, forest, rangeland cover types) at two buffer scales: $0.5 \mathrm{~km}$ (0.31 miles) and $3.0 \mathrm{~km}$ (1.86 miles). However, mean cover of forest (conifer and deciduous) was significantly greater at the $3.0 \mathrm{~km}$ buffer around day roosts $(35.9 \%)$ than at night roosts $(22.1 \%)$ or unused structures $(15.1 \%)$. Nevertheless, percent forest cover was as low as $0 \%$ at one day roost, and maximum percent forest cover for some night roosts and unused structures exceeded that of any day roost. There was a similar lack of landscape influence on the relative intensity of use of structures for night roosting.

Bats used $75.9 \%$ of concrete structures, $37.5 \%$ of steel structures, and $31.6 \%$ of wooden ones. Significantly more $\mathrm{T}$-beam and box-beam concrete structures were used than slab ones. Night roosts were found in a wider variety of bridges than day roosts, and included one steel culvert. Night roost locations on bridges tended to be relatively exposed: typically the vertical face of a girder (concrete or steel) near the abutment with the underside of the deck and in darker areas between girders and close to the intersection with the ground or embankment. Day roosts were in narrow vertical spaces $3-5 \mathrm{~cm}$ (1.25-2.0 inches) wide and at least 11-20 cm (4.5-8.0 inches) deep in wood or concrete bridges; three maternity colonies (up to 130 adults) were in wood bridges, one in a concrete bridge. All day roosts in wood bridges were underneath the deck, but five of seven in concrete bridges were in expansion joints between deck sections and near the deck edge. 


\section{DISCLAIMER STATEMENT}

This document is disseminated under the sponsorship of the Montana Department of Transportation and the United States Department of Transportation in the interest of information exchange. The State of Montana and the United States Government assume no liability of its contents or use thereof.

The contents of this report reflect the views of the authors, who are responsible for the facts and accuracy of the data presented herein. The contents do not necessarily reflect the official policies of the Montana Department of Transportation or the United States Department of Transportation.

The State of Montana and the United States Government do not endorse products of manufacturers. Trademarks or manufacturers' names appear herein only because they are considered essential to the object of this document.

\section{ALTERNATIVE FORMAT STATEMENT}

The Montana Department of Transportation attempts to provide reasonable accommodations for any known disability that may interfere with a person participating in any service, program, or activity of the Department. Alternative accessible formats of this document will be provided upon request. For further information, call (406) 444-7693 or TTY (406) 444-7696.

\section{ACKNOWLEDGMENTS}

The authors are particularly grateful to John Carlson, former Program Zoologist with the Montana Natural Heritage Program (MNHP), for escorting the original proposal through the administrative process and securing the Cost Reimbursement Contract that funded the study presented in this report. The authors thank Larry Urban of the Montana Department of Transportation (MDT) for being receptive to the initial idea of the survey, and Susan Sillick (MDT) and Jim Hill (Natural Resources Information System) for administering the contract. For help in production of this report the authors thank Whitney Weber (MNHP) for making the map and determining the areal extent of cover types for our landscape analyses, and Bryce Maxell (MNHP) for final edits and formatting help.

The preferred citation for this document is:

Hendricks, P., S. Lenard, C. Currier, and J. Johnson. 2005. Bat use of highway bridges in southcentral Montana. Report to Montana Department of Transportation. Montana Natural Heritage Program, Helena. 31 pp. 


\section{TABLE OF CONTENTS}

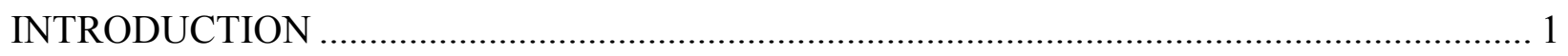

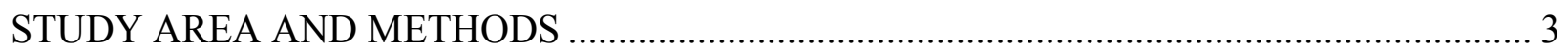

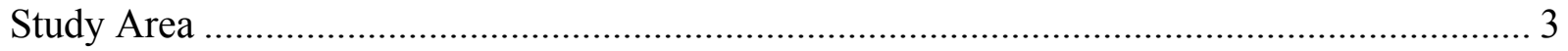

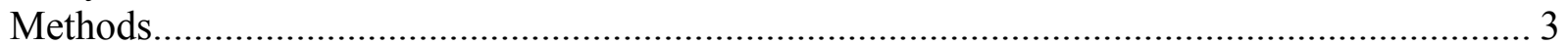

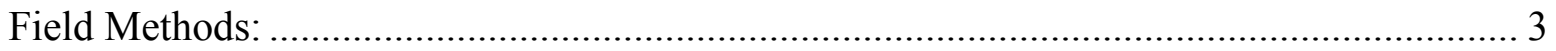

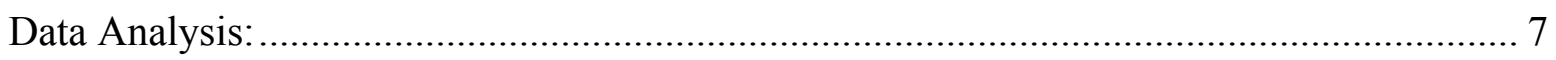

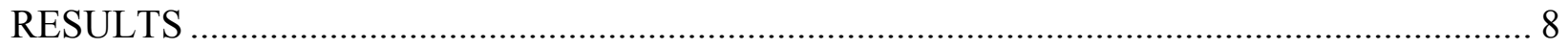

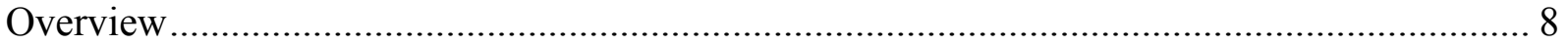

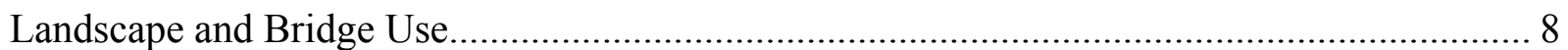

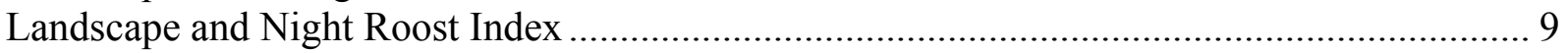

Structure Materials, Structure Design, and Bat Use ………............................................... 10

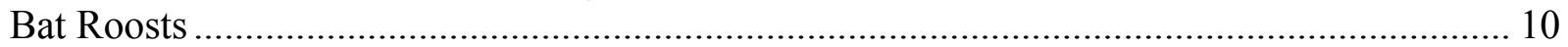

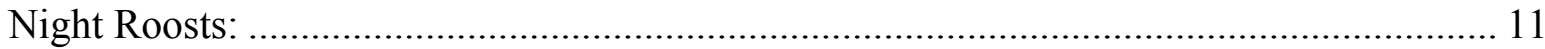

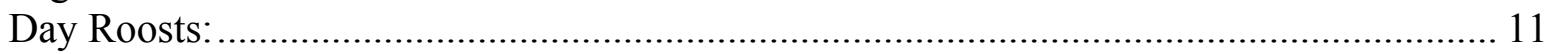

Maternity Colonies: .................................................................................................. 17

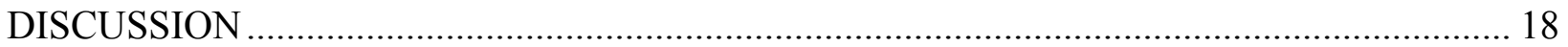

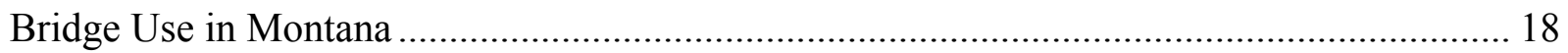

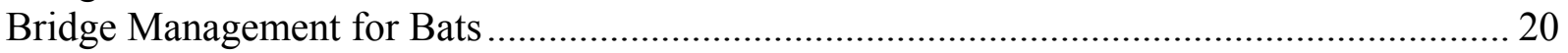

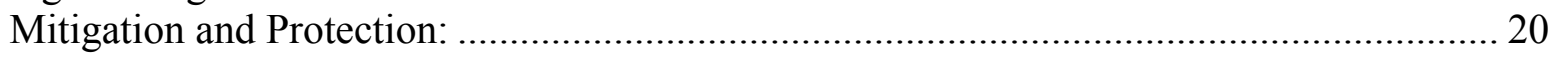

Excluding Bats from Day Roost Structures:......................................................................... 21

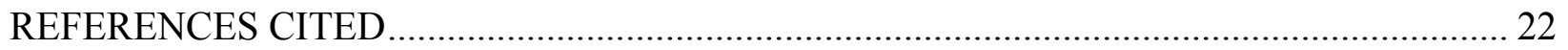

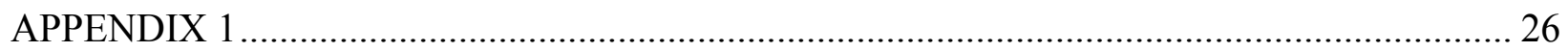

\section{FIGURES}

Figure 1. The three-county area in south-central Montana where highway structures were surveyed for use by bats in summer 2003 ............................................................ 4

Figure 2. Droppings to the left of the hand at a concrete T-beam night roost............................. 5

Figure 3. Urine stain on underside of a concrete T-beam night roost.......................................... 5

Figure 4. Concrete T-beam night roost on US 212 above Rock Creek. .................................... 6

Figure 5. Steel bridge with concrete deck on Highway 310 near Warren, MT. ............................. 6

Figure 6. Wood girder bridge on State 78 near Columbus. ........................................................ 6

Figure 7. Maternity colony of Big Brown Bats in the slot of a wood bridge next to the pole tip,

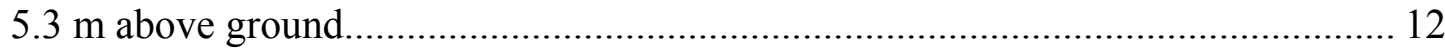

Figure 8. Maternity colony of Big Brown Bats at bridge shown in Figure 7 .......................... 12

Figure 9. Site of maternity colony of Little Brown Myotis in slot between braces and behind

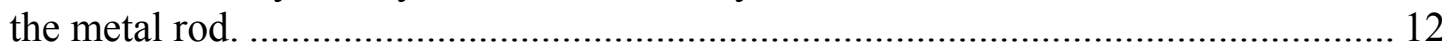

Figure 10. Little Brown Myotis maternity colony in a site like that in Figure 9, along a frontage road east of Pompeys Pillar.................................................................................... 12 
Figure 11. Day roost site between US 87 bridge spans, Yellowstone River in Billings, MT. .... 13

Figure 12. Occupied day roost between abutting US 87 bridge spans shown in Figure $11 \ldots \ldots .13$

Figure 13. Day roost of Big Brown Bats in expansion joint between two concrete sections of State 306 crossing I-90; bats above the fill material............................................. 13

Figure 14. Day roost of Big Brown Bats in the expansion joint between two concrete sections of I-90, west bound 13

Figure 15. Big Brown Bat day roost in expansion joint of I-90, west bound, $9.8 \mathrm{~m}(32.2 \mathrm{ft})$ above ground.

Figure 16. Big Brown Bat day roost in expansion joint of concrete bridge on frontage road west of Columbus. 14

\section{TABLES}

Table 1. Distribution of highway structures surveyed in 2003, based on highway type in the MDT system, and number of structures used by bats.

Table 2. Mean percent land cover at $0.5 \mathrm{~km}(0.31 \mathrm{miles})$ around unused structures, night roosts, and day roosts.

Table 3. Mean percent land cover at $3.0 \mathrm{~km}$ (1.86 miles) around unused structures, night roosts, and day roosts.

Table 4. Mean percent land cover at $0.5 \mathrm{~km}$ (0.31 miles) around different intensity-of-use categories for structures used as night roosts. Index scores: $1=$ minute amount of sign in only one location, 2 = scattered small amounts of sign, $3=$ moderate amounts of sign widespread but spotty, 4 = large accumulations of droppings or wet urine stains widespread but spotty.

Table 5. Mean percent land cover at $3.0 \mathrm{~km}$ (1.86 miles) around different intensity-of-use categories for structures used as night roosts. Index scores are described in Table 4. . 10

Table 6. Bat use of highway structures of different construction materials in south-central Montana, 2003.

Table 7. Bat occupancy (adults) at day roosts discovered in 2003 in south-central Montana highway structures.

Table 8. Bat occupancy (adults) in 2004 at the day roosts discovered in 2003 in south-central Montana highway structures. 


\section{INTRODUCTION}

There has been growing concern in recent decades regarding the status of bats throughout North America, in part because a variety of habitats used by bats for roosting and foraging have been subjected to widespread disturbance, alteration, reduced availability, or complete removal $(1,2)$. As a result, six species or subspecies of bats in the continental United States currently are classified as endangered under the United States Endangered Species Act of 1973 (3), although none of these bats occur in Montana.

Conservation efforts for bats are often hampered by a lack of data on their habitat requirements. This means there is considerable uncertainty about how to offer them the most effective protection, be it directed to the bats themselves, their foraging areas, or their roosts (1). Nevertheless, suitable summer and winter roosts may limit local and regional distribution and abundance of many temperate-zone bats $(4,5)$, especially cave- and crevice-dwelling taxa. Thus conservation and protection of roosts are important long-term management activities for many North American bat species (6).

Many bat species use a variety of localized habitats for roosting, be they natural sites (e.g., caves, trees, rock crevices) or man-made sites (e.g., buildings, mines, bridges). Sites may be used only during specific seasons of the year, and then for different purposes (e.g., a cave may be used only during winter for hibernation, while a building may be used only during summer as a maternity roost). Much research in the past has focused on roosts that are the most accessible, such as caves and buildings, with less attention to tree, mine, and cliff roosts (2). Although bats make extensive use of bridges as both day and night roosts (7), bridge use has received relatively little attention. Recent research on bat roosts in Montana has followed the general national pattern by concentrating on roosts in caves and abandoned mines (e.g., 8,9); no studies of bridge use by bats have been conducted in the state.

Prior to the early 1960 's, bridges generally were overlooked as potential roosting habitat for bats (10), although it is recognized now that they provide bats with roost sites that are relatively cryptic with generally low levels of human disturbance (2). Thus, in recent years studies have begun to document the magnitude and frequency of bridge use for night and day roosting by several bat species (e.g.,11, 12, 13, 14, 15). A large-scale survey of 2,421 highway structures across the southern and western United States ( 25 states) by Bat Conservation International (BCI) documented 17 bat species using bridges and culverts (7). The BCI survey also identified features of highway structures that make them most attractive as roosting habitat for bats, and provided guidelines and suggestions for conducting surveys. The BCI survey prompted our study of highway structures in Montana.

Montana was not included in the BCI survey because it was one of the northern states where few highway structures were considered warm enough to meet bat needs (7). However, brief surveys of bridges along the Gibbon River in Yellowstone National Park, Wyoming provided evidence of night roosting by bats (16), indicating that bridge use in Montana may be more prevalent than suggested in the BCI survey. We therefore designed a study to quantify the frequency of bridge use in a relatively small portion of Montana, with the added goals of determining 1) bridge attributes that make structures more attractive to bats, 2) bridge attributes that contribute to their 
use as night roosts versus day roosts, and 3) features of the surrounding landscape (cover types) that might correspond to bridge use by bats. Additional benefits provided by our study are the identity of specific highway structures currently or recently used by bats, and the provision to MDT biologists and engineers of field-tested techniques applied in Montana for determining bat use during routine inspections of bridges and culverts. This information will prove useful for future surveys of highway structures, and contribute to the conservation of bat roosting habitat in the state. 


\section{STUDY AREA AND METHODS}

\section{Study Area}

Our survey of highway structures (mostly bridges, but including a few culverts) was concentrated in three counties in south-central Montana: Carbon, Stillwater, and Yellowstone (Figure 1). This region in the MDT Billings Division was chosen for study because 1) it supports probably the greatest diversity of bat species (10 confirmed) in Montana (17), including three species on the joint Montana Natural Heritage Program/Montana Fish, Wildlife and Parks Animal Species of Concern list (18), and 2) prior (19, 20, 21, 22) and concurrent studies in the Pryor Mountains and along the Yellowstone River (MNHP) help place our highway survey results in a larger landscape context.

The three-county study area is roughly bounded by Wyoming on the south, the Bull Mountains on the north, Reed Point in the west, and Custer in the east $\left(45^{\circ} 00^{\prime}\right.$ to $46^{\circ} 30^{\prime} \mathrm{N}, 107^{\circ} 30^{\prime}$ to $\left.110^{\circ} 00^{\prime} \mathrm{W}\right)$. Interstates 90 and 94 parallel the Yellowstone River and bisect the study area from west to east. Elevations in the survey area ranged from 820-3000 m (2690-9850 ft), but only one bridge we examined was at an elevation exceeding $1550 \mathrm{~m}(5085 \mathrm{ft})$.

Based on the U.S. Forest Service's National Hierarchical Framework of Ecological Units, the study area largely occurs in the Powder River Basin Section, with a portion of Carbon County in the Bighorn Basin Section (23). The area is characterized by a cold continental climate with warm to hot, dry summers and cold, dry winters. Mean annual precipitation ranges from 25.5$35.5 \mathrm{~cm}$ (10-14 inches) in the Powder River Basin Section, with 30 percent falling as snow; in the Bighorn Basin Section, mean annual precipitation is $12.5-30.5 \mathrm{~cm}$ (5-12 inches). It is an area with large expanses of prairie grass- and shrub-land and scattered highlands largely of sandstone and shale that support ponderosa pine (Pinus ponderosa) woodland. Flood plain cottonwood (Populus deltoides) gallery forest and other riparian woodlands are present along the Yellowstone River and tributaries. Land use in both sections is largely livestock grazing and some dryland farming, with strips of irrigated farmland along river and stream bottoms. One large urban center, Billings, also is present in the study area.

\section{Methods}

\section{Field Methods:}

Highway structures to be inspected for use by bats were initially identified using the MDT Bridge Management System Bridge Inventory Books, available on-line with permission from Montana Department of Transportation. The appropriate inventory books were printed and used to conduct surveys and identify structures as they were encountered. We conducted a preliminary inspection of the inventory books prior to field inspections to be sure a diversity of structures was present in the study area, because we wanted to determine if bats selectively use certain kinds of bridges.

General bridge surveys were conducted during daylight hours in 2003 (14-19 July, 19-21 August, 9, 12-13 and 16 September). In 2004 (7 and 10 June, 21-22 July, 26-27 August, 1 October) we focused on monitoring occupancy of the day roost structures identified in 2003 . We inspected the undersides of bridges and looked for evidence of bat use especially on support beams and ledges on pillars; evidence of night roosting included the presence of droppings and/or urine staining in the absence of bats (Figures 2 and 3). We also examined crevices and 


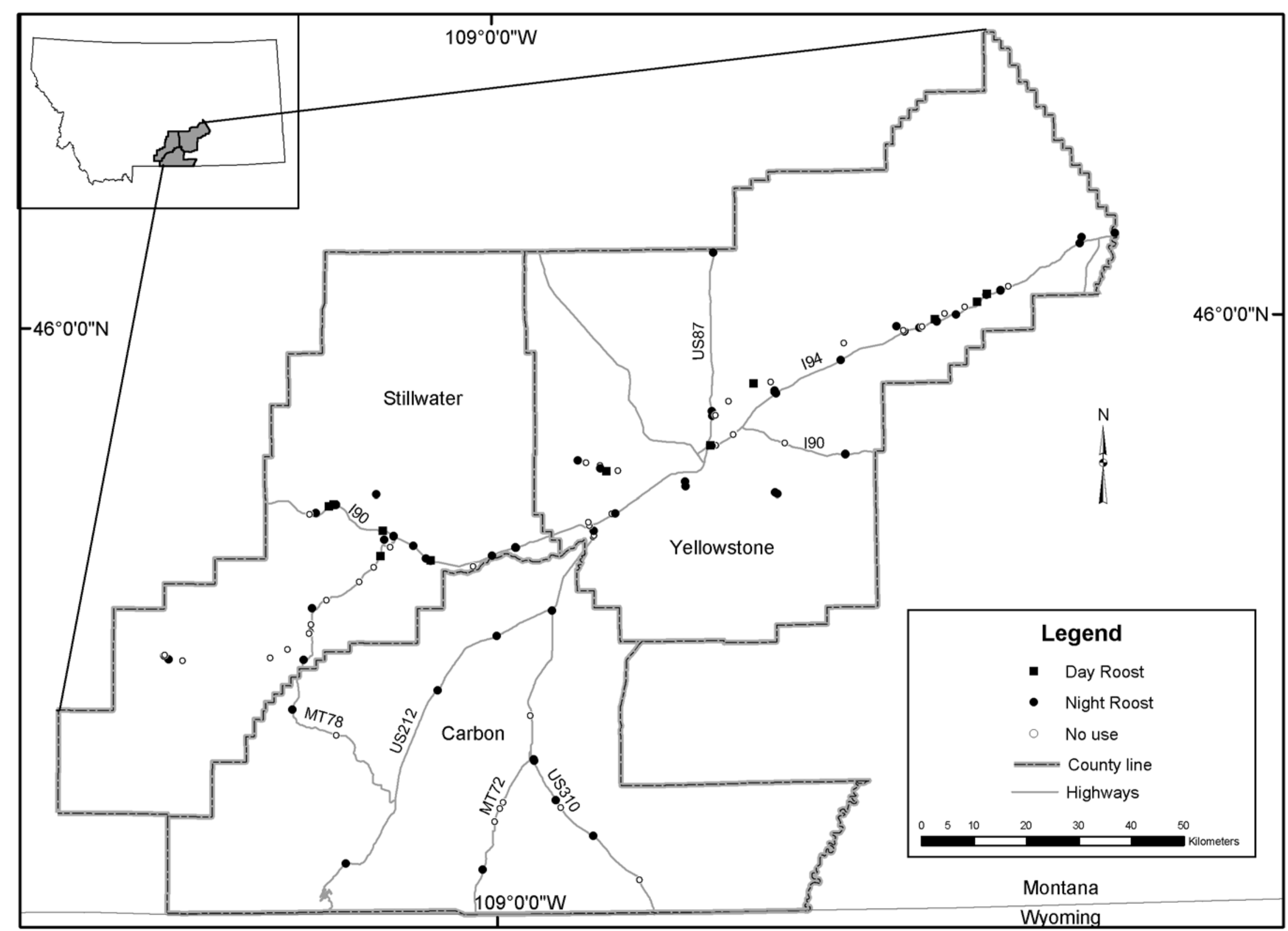

Figure 1. The three-county area in south-central Montana where highway structures were surveyed for use by bats in summer 2003. 
gaps between deck sections with a Vector "Super Sport Spot" one million candle power portable spotlight and an 8-power binocular, looking for the presence of day- roosting bats. Although we had extendible-pole mini-camera units built for examining remote crevices, the spotlight and binocular system worked equally well for our inspections, and we favored their use in almost all situations. An ultrasound bat detector (Pettersson D240x) was also used in some circumstances to help determine the presence day-roosting bats, although all of the day roosts we located during the survey were discovered without the aid of a detector.

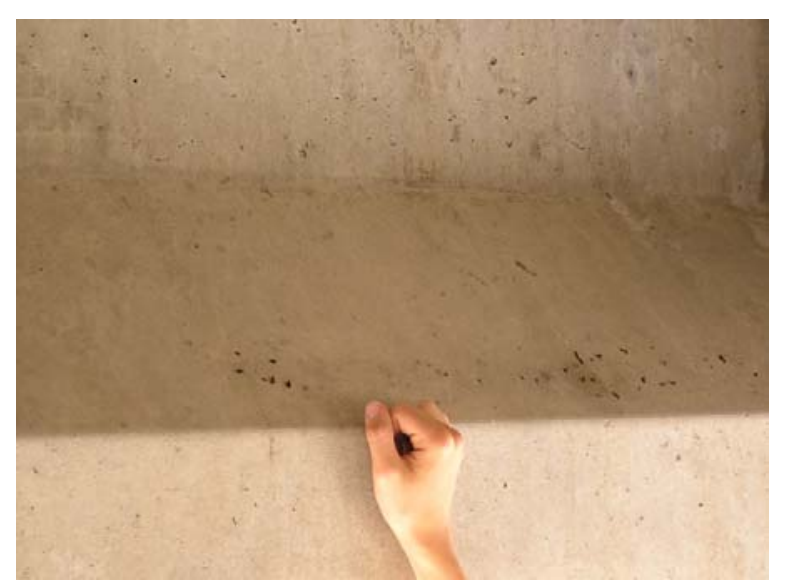

Figure 2. Droppings to the left of the hand at a concrete T-beam night roost.

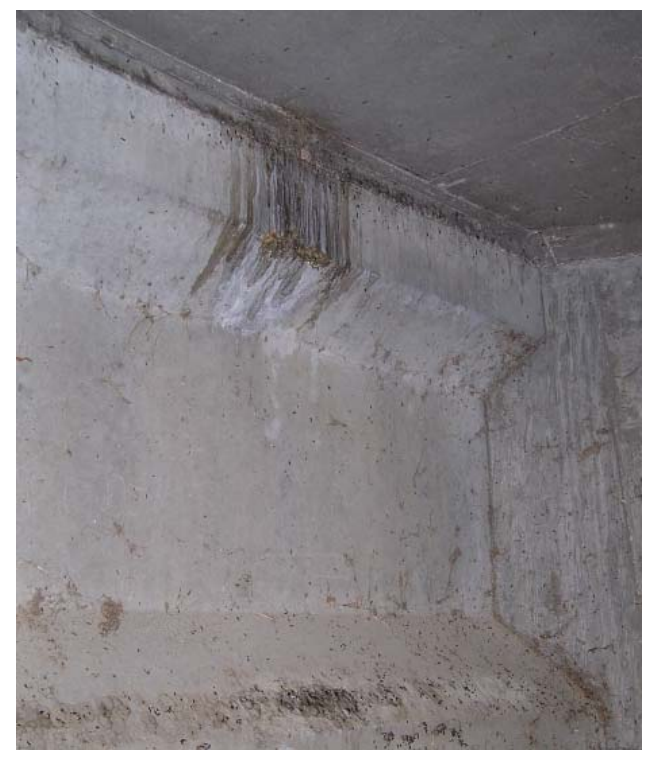

Figure 3. Urine stain on underside of a concrete T-beam night roost.

At each structure we noted the MDT bridge number, date of our inspection, GPS location (using a Garmin GPSmap 76 unit), construction material (concrete, steel, wood) and design (I-beam, Tbeam, box-beam, slab, wooden girder) of the support structure (Figures 4-6), evidence of bat use (droppings, urine staining, bats), and height above ground of roost sites; each structure was also assigned an index score of use $(0=$ no sign, $1=$ minute amount of sign in only one location, $2=$ scattered small amounts of sign, $3=$ moderate amounts of sign widespread but spotty, $4=$ large accumulations of droppings or wet urine stains widespread but spotty). Index scoring and other variables we recorded followed Bat Conservation International suggestions (7).

When bats were discovered at a structure, we noted the species (based on prior experience and species descriptions in van Zyll de Jong [24] and Nagorsen and Brigham [25]), estimated the number of adults present, looked for evidence (pups) that the roost was a maternity colony, and measured the height above ground of the roost with a meter tape and pole (or estimated the roost height). In-hand identification of bats was made at one accessible maternity colony to verify initial identification. Day roosts were visited two or more times each year to obtain a time-series measure of roost occupancy and site fidelity. 


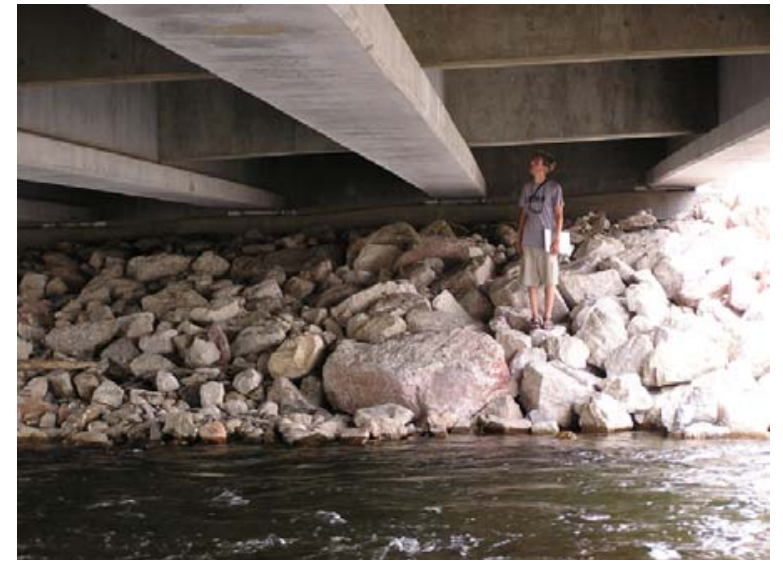

Figure 4. Concrete T-beam night roost on US 212 above Rock Creek.

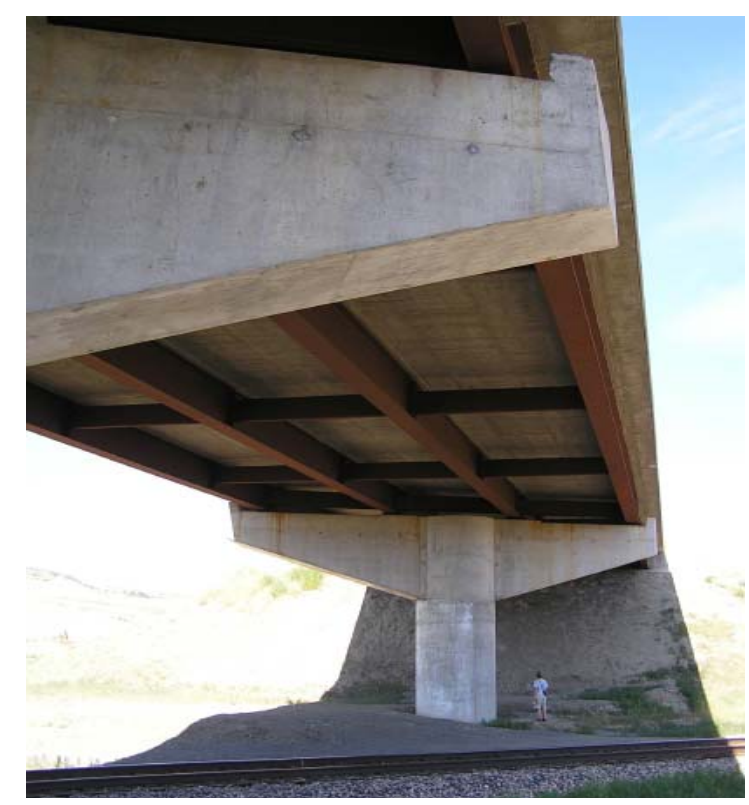

Figure 5. Steel bridge with concrete deck on Highway 310 near Warren, MT.

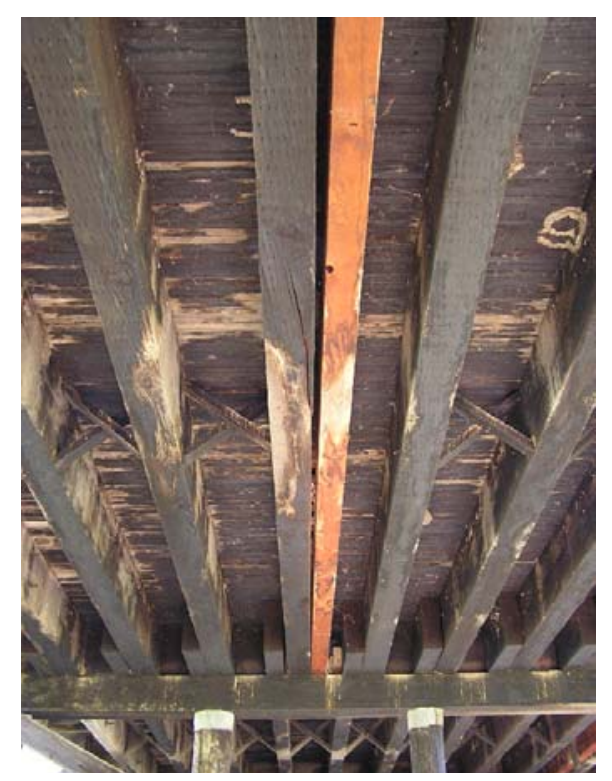

Figure 6. Wood girder bridge on State 78 near Columbus. 
Data Analysis:

Landscapes around each highway structure we inspected were analyzed at radii of $0.5 \mathrm{~km}(0.31$ miles) and $3.0 \mathrm{~km}$ (1.86 miles) to look for possible relationships between adjacent land cover types and structure use by bats. For these analyses, we used the data layer Montana 1:250,000 scale Land Use/Cover from USGS (http://nris.state.mt.us/nsdi/nris/LU25.html). Nineteen cover types within the study area were merged to a set of five we determined were most appropriate for our analyses: 1) Agriculture (crop/pasture, other agriculture), 2) Aquatic/wetland (reservoir, stream/canal, wetland), 3) Commercial/urban (commercial services, industrial, mines/quarries, mixed urban, other urban, transportation/utility, residential, confined feeding), 4) Forest (deciduous forest, evergreen forest, mixed forest), and 5) Rangeland (brush rangeland, grass rangeland, mixed rangeland). Percent cover for each of the five types was calculated for each structure at each radius, mean percent cover values were then calculated for various categories of bat use (roost type, index score), and statistical analysis of the influence of landscape composition on bridge use by bats was conducted using a non-parametric ANOVA (analysis of variance).

We conducted statistical analyses of categorical variables (e.g., index measures of bat use of highway structures and the construction material or design of the structures) using nonparametric tests. Continuous variables (e.g., comparisons in height of day and night roosts) were analyzed using parametric tests; parametric tests were adjusted to account for non-homogeneous variances among groups when this assumption was not satisfied.

All statistical tests were run on Statistix ${ }^{\circledR}$ for Windows version 2.0 (Analytical Software, Tallahassee, Florida), and followed standard procedures (e.g., 26); statistical significance was assumed when $\mathrm{P}<0.05$. 


\section{RESULTS}

\section{Overview}

We visited 136 highway structures during summer 2003; six (five bridges, one culvert) were completely inaccessible for inspection due to high water levels. The 130 structures inspected included 125 bridges and five culverts (Appendix 1) distributed in Carbon County (15 structures), Stillwater County (45 structures), and Yellowstone County (70 structures). Of these, 45 structures were on the Interstate System, 36 on the Primary System, 28 on the Secondary System, and 25 on the Local State Maintained System (Table 1).

Table 1. Distribution of highway structures surveyed in 2003, based on highway type in the MDT system, and number of structures used by bats.

\begin{tabular}{|l|c|c|c||}
\hline \multicolumn{1}{|c|}{$\begin{array}{c}\text { Highway System } \\
\text { Category }\end{array}$} & $\begin{array}{c}\text { Number of } \\
\text { Structures Surveyed }\end{array}$ & $\begin{array}{c}\text { Number Used } \\
\text { by Bats }\end{array}$ & $\begin{array}{c}\text { Number of } \\
\text { Day Roosts }\end{array}$ \\
\hline \hline Interstate & 41 & 30 & 3 \\
\hline Primary & 36 & 17 & 2 \\
\hline Secondary & 28 & 16 & 2 \\
\hline Local/State Maintained & 25 & 15 & 5 \\
\hline
\end{tabular}

We found evidence of bat use at 78 structures (60.0\%); 66 structures (65 bridges, one culvert) apparently were used exclusively as night roosts, and 12 bridges were day roosts. Bats used structures relatively evenly among the highway categories, from $47.2 \%$ of Primary System structures examined to $73.2 \%$ of Interstate System structures (Table $1: \chi^{2}=5.51, \mathrm{df}=3, \mathrm{P}=$ 0.138). For structures used as roosts, relatively more day roosts occurred in Local/State Maintained System structures (33.3\%) than in other parts of the system (10.0-12.5\%), but the difference among highway categories we surveyed was not statistically significant (Table $1: \chi^{2}=$ $4.65, \mathrm{df}=3, \mathrm{P}=0.199)$; this result is likely influenced by the small sample of day roosts.

\section{Landscape and Bridge Use}

There were few indications of any relationships between the use of highway structures by bats and the immediate or nearby landscapes in which they were located, with the exception of surrounding forest cover. Bridges used as day roosts tended to occur where forest cover was greater than around unused structures and night roosts (Tables 2 and 3). Mean forest cover at day roosts was $18.0 \%$ in the surrounding $0.5 \mathrm{~km}(0.31$ miles $)$ radius, compared to $10.4-11.3 \%$ at night roosts and unused structures $(\mathrm{P}=0.097)$. At the $3.0 \mathrm{~km}(1.86 \mathrm{miles})$ radius, mean forest cover around night roosts was $35.9 \%$ compared to $15.1-22.1 \%$ for unused structures and night roosts; the difference was statistically significant $(\mathrm{P}=0.009)$.

Although mean forest cover was greatest at day roosts, minimum cover for the sample of day roosts was $0 \%$ at one structure and $<10 \%$ at two others, at the $3 \mathrm{~km}$ (1.86 miles) radius. Maximum forest cover around day roosts $(68.9 \%)$ was exceeded around both unused structures (71.7\% maximum) and night roosts $(96.5 \%$ maximum) at the $3.0 \mathrm{~km}(1.86$ miles $)$ buffer. The range in percent cover greatly overlapped among structure-use categories for all cover types at both buffer distances. 
Table 2. Mean percent land cover at $0.5 \mathrm{~km}(0.31 \mathrm{miles})$ around unused structures, night roosts, and day roosts.

\begin{tabular}{|l|c|c|c|c|c|}
\hline \multicolumn{1}{|c|}{ Cover Type } & $\begin{array}{c}\text { No Bats } \\
(\mathbf{n = 5 2})\end{array}$ & $\begin{array}{c}\text { Night Roost } \\
(\mathbf{n = ~ 6 6 )}\end{array}$ & $\begin{array}{c}\text { Day Roost } \\
(\mathbf{n = 1 2})\end{array}$ & $\mathbf{H}^{\mathbf{a}}$ & $\mathbf{P}$ \\
\hline \hline Agriculture & 54.2 & 48.5 & 50.8 & 0.858 & 0.651 \\
\hline Aquatic/wetland & 2.9 & 4.5 & 4.3 & 0.631 & 0.730 \\
\hline Commercial/urban & 15.9 & 16.9 & 17.8 & 2.037 & 0.361 \\
\hline Forest & 11.3 & 10.4 & 18.0 & 4.676 & 0.097 \\
\hline Rangeland & 13.3 & 19.1 & 8.6 & 2.584 & 0.275 \\
\hline
\end{tabular}

${ }^{\mathrm{a}}$ Kruskal-Wallis one-way ANOVA.

Table 3. Mean percent land cover at $3.0 \mathrm{~km}$ (1.86 miles) around unused structures, night roosts, and day roosts.

\begin{tabular}{|l|c|c|c|c|c||}
\hline \multicolumn{1}{|c|}{ Cover Type } & $\begin{array}{c}\text { No Bats } \\
(\mathbf{n}=\mathbf{5 2})\end{array}$ & $\begin{array}{c}\text { Night Roost } \\
(\mathbf{n}=\mathbf{6 6})\end{array}$ & $\begin{array}{c}\text { Day Roost } \\
(\mathbf{n = 1 2})\end{array}$ & $\mathbf{H}^{\mathbf{a}}$ & $\mathbf{P}$ \\
\hline \hline Agriculture & 39.4 & 41.4 & 35.2 & 1.325 & 0.516 \\
\hline Aquatic/wetland & 2.8 & 3.3 & 2.9 & 1.760 & 0.415 \\
\hline Commercial/urban & 7.8 & 4.7 & 7.6 & 0.807 & 0.668 \\
\hline Forest & 15.1 & 22.1 & 35.9 & 9.446 & 0.009 \\
\hline Rangeland & 30.4 & 27.9 & 17.3 & 2.741 & 0.254 \\
\hline
\end{tabular}

${ }^{\mathrm{a}}$ Kruskal-Wallis one-way ANOVA.

\section{Landscape and Night Roost Index}

A similar general lack of relationship between land cover surrounding highway structures and the intensity of their use for night roosting by bats was evident in our analysis (Tables 4 and 5). Only agricultural lands appeared to be more extensive on average $(69.9 \%)$ in the immediate 0.5 $\mathrm{km}$ (0.31 miles) surrounding structures showing the most sign of bat use (index scores $>2)$, but this slight trend disappeared at the $3 \mathrm{~km}$ (1.86 miles) radius. The range in percent cover greatly overlapped among night-roost use categories for all cover types at both buffer distances.

Table 4. Mean percent land cover at $0.5 \mathrm{~km}$ (0.31 miles) around different intensity-of-use categories for structures used as night roosts. Index scores: $1=$ minute amount of sign in only one location, 2 = scattered small amounts of sign, 3 = moderate amounts of sign widespread but spotty, $4=$ large accumulations of droppings or wet urine stains widespread but spotty.

\begin{tabular}{|l|c|c|c|c|c||}
\hline \multicolumn{1}{|c|}{ Cover Type } & $\begin{array}{c}\text { Roost Index 1 } \\
(\mathbf{n}=\mathbf{1 4})\end{array}$ & $\begin{array}{c}\text { Roost Index 2 } \\
(\mathbf{n}=\mathbf{4 5})\end{array}$ & $\begin{array}{c}\text { Roost Index 3-4 } \\
(\mathbf{n}=\mathbf{7})\end{array}$ & $\mathbf{H}^{\mathbf{a}}$ & $\mathbf{P}$ \\
\hline Agriculture & 38.6 & 49.0 & 69.9 & 5.293 & 0.071 \\
\hline Aquatic/wetland & 3.7 & 5.1 & 2.1 & 0.170 & 0.919 \\
\hline Commercial/urban & 24.4 & 15.5 & 10.3 & 2.900 & 0.235 \\
\hline Forest & 12.6 & 10.5 & 8.5 & 0.173 & 0.917 \\
\hline Rangeland & 20.3 & 19.9 & 8.7 & 1.025 & 0.599 \\
\hline
\end{tabular}

${ }^{\mathrm{a}}$ Kruskal-Wallis one-way ANOVA. 
Table 5. Mean percent land cover at $3.0 \mathrm{~km}$ (1.86 miles) around different intensity-of-use categories for structures used as night roosts. Index scores are as described in Table 4.

\begin{tabular}{|l|c|c|c|c|c|}
\hline \multicolumn{1}{|c|}{ Cover Type } & $\begin{array}{c}\text { Roost Index 1 } \\
(\mathbf{n = ~ 1 4 )}\end{array}$ & $\begin{array}{c}\text { Roost Index 2 } \\
(\mathbf{n = 4 5 )}\end{array}$ & $\begin{array}{c}\text { Roost Index 3-4 } \\
(\mathbf{n = 7})\end{array}$ & $\mathbf{H}^{\mathbf{a}}$ & $\mathbf{P}$ \\
\hline Agriculture & 45.7 & 38.8 & 50.0 & 2.558 & 0.278 \\
\hline Aquatic/wetland & 3.4 & 3.7 & 1.4 & 2.595 & 0.273 \\
\hline Commercial/urban & 4.6 & 5.1 & 2.0 & 2.715 & 0.257 \\
\hline Forest & 16.9 & 22.7 & 25.6 & 1.243 & 0.537 \\
\hline Rangeland & 28.8 & 29.0 & 20.5 & 1.150 & 0.563 \\
\hline
\end{tabular}

${ }^{\mathrm{a}}$ Kruskal-Wallis one-way ANOVA.

\section{Structure Materials, Structure Design, and Bat Use}

The 130 highway structures we examined included 125 bridges and five culverts. Structures included $79(60.8 \%)$ made of concrete, 32 (24.6\%) of steel (32), and 19 (14.6\%) of wood (Table 6 , Appendix 1). Bridges were classified according to the type of construction material used for the girders (if present), or the underside of the decking if girders were absent. Of the 32 steel structures, four were culverts, three were bridges with wooden decks, and the remaining 25 were bridges with concrete decks. All wooden structures were bridges classified as girder design, all steel bridges were classified as I-beam design, and concrete bridges were classified as T-beam (62), box-beam (3), or slab design (13); there was one concrete culvert.

Number of concrete structures used by bats $(75.9 \%)$ exceeded use of steel $(37.5 \%)$ or wooden $(31.6 \%)$ ones (Table $\left.6: \chi^{2}=21.52, \mathrm{df}=2, \mathrm{P}<0.0001\right)$; only one steel culvert of five culverts total had sign of bat use. Among concrete bridges (not including one concrete culvert), only four $(30.8 \%)$ of the slab bridges were used, compared to $56(86.2 \%)$ of the T-beam and box-beam bridges (Yates corrected $\chi^{2}=15.73, \mathrm{df}=1, \mathrm{P}=0.0001$ ). None of the steel bridges with wooden decks had sign of bat use, whereas 11 of 25 with concrete decks were classified as night roosts (Fisher Exact test: $\mathrm{P}=0.258$ ).

Table 6. Bat use of highway structures of different construction materials in south-central Montana, 2003.

\begin{tabular}{|l|c|c|c|}
\hline Construction Material & $\begin{array}{c}\text { Number of } \\
\text { Structures }\end{array}$ & $\begin{array}{c}\text { Number Used } \\
\text { by Bats }\end{array}$ & $\begin{array}{c}\text { Number of Day } \\
\text { Roosts }\end{array}$ \\
\hline Concrete & 79 & 60 & 7 \\
\hline Steel & 32 & 12 & 0 \\
\hline Wood & 19 & 6 & 5 \\
\hline
\end{tabular}

\section{Bat Roosts}

Bats used the highway structures we sampled for two primary purposes: night roosting (nocturnal rest stops for digesting meals in a protected location), and day roosting (diurnal sites protected from weather and predators for raising young and/or sleeping). Sixty-six structures were classified as night roosts exclusively, 12 structures where we found bats during the day were classified as day roosts. All but one of seven concrete bridges used as a day roost also had 
sign in other parts of the structure indicating some use for night roosting. We found no evidence of night roosting at the wooden bridges where we found day roosting bats.

\section{Night Roosts:}

We found night roosts in a wider variety of bridges than day roosts (Table 6, Appendix 1), and also in one steel culvert. The identity of bats using various structures for night roosting was not possible during our survey because we surveyed bridges only during the day. Nevertheless, two distinct sizes of droppings indicated at least two bat species were using some of the structures. At one concrete bridge examined on 16 July in Carbon County we found a solitary Little Brown Myotis (Myotis lucifugus), probably sick, that was roosting in an exposed location on a girder (Appendix 1); no bats were present at this structure during additional checks on 19 August and 9 September. The location where this bat was found was typical for night roosting sites we found on other concrete (and steel) spans: the exposed vertical face of a girder near where the girder abuts the underside of the deck, most often in the darker areas between beams and close to where the deck intersects the ground or embankment. Average minimum height above ground of night roost sites was $2.1 \pm 0.9 \mathrm{~m}(6.9 \pm 3.0 \mathrm{ft})$, while average minimum for day roost sites was $4.8 \pm 2.4 \mathrm{~m}$ $(15.7 \pm 7.9 \mathrm{ft})(t$ adjusted for unequal variances $=3.83, \mathrm{P}=0.0026)$; one day roost was $9.8 \mathrm{~m}(32.2$ $\mathrm{ft})$ above ground.

\section{Day Roosts:}

All day-roosting bats we found were positioned in narrow vertical spaces about $3-5 \mathrm{~cm}(1.25-2.0$ inches) wide and estimated to be at least 11-30 cm (4.5-12.0 inches) deep in wood or concrete bridges (Table 6). Bats occupying wood bridges were found on the undersides of the deck, either in slots between parallel beams (Figures 7-8) or between supports where railing posts were anchored (Figures 9-10) Bats occupying concrete spans were found in two general locations: 1) on the undersides of bridges in the narrow slots of the deck of a box-beam bridge, and in the space between two abutting T-beam bridges crossing the Yellowstone River (Figures 11-12), or 2 ) in the spacing between span sections (expansion joints) near the outer edge of the bridge deck where cushion material had eroded (Figures 13-16). Occupied slots of this kind were on the south (2), north (2), and west (1) exposures of bridges. Wood bridges in our study area were more likely to house day-roosting bats than concrete bridges (26.3\% vs. $9.0 \%$, respectively) $($ Fisher Exact test $=0.0545)$.

We identified four species of bats in 2003 using 12 separate bridges (five wood, seven concrete) as day roosts (Figure 1, Tables 7-8): Big Brown Bat (Eptesicus fuscus) in ten, Hoary Bat (Lasiurus cinereus) in one, Little Brown Myotis (Myotis lucifugus) in two, and Western Smallfooted Myotis (M. ciliolabrum) in two. In 2004, we identified only Big Brown Bat (at six of ten bridges used in 2003) and Little Brown Myotis (at four bridges, including the two used in 2003); one bridge was used by both species (Table 8).

A day roost found in 2003 with eight roosting adult Big Brown Bats might have been a small maternity colony, but we saw no dependent young, and assume it was a group of males or nonreproductive females; in 2004 this bridge was occupied by four Big Brown Bats, but only during the July visit. In a different situation, a group of 17 Big Brown Bats appeared in late August 2004 at a roost previously occupied in late July by a single bat; we assume the group was dispersing, and not a maternity colony. Lone roosting bats and pairs were probably males, with 


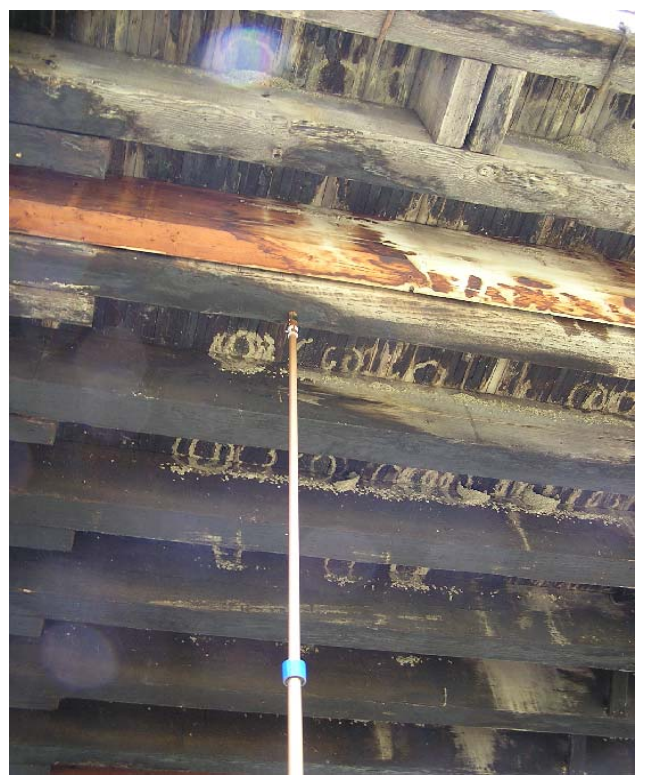

Figure 7. Maternity colony of Big Brown Bats in the slot of a wood bridge next to the pole tip, $5.3 \mathrm{~m}$ above ground.

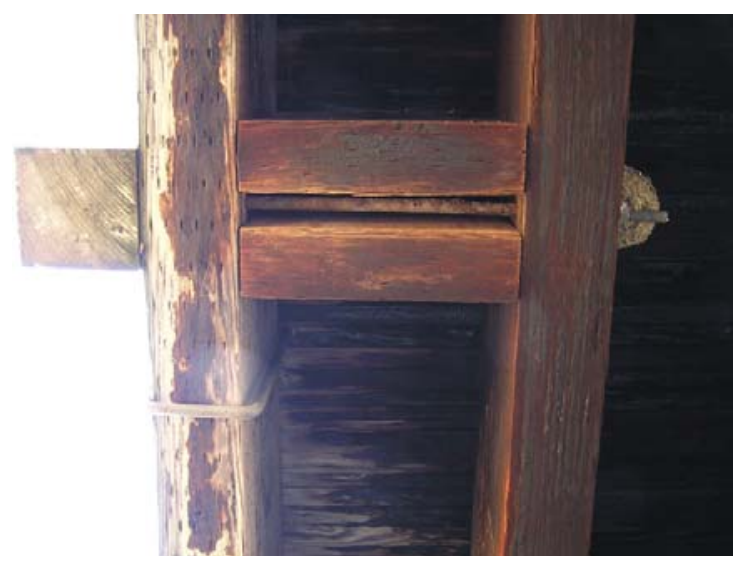

Figure 9. Site of maternity colony of Little Brown Myotis in slot between braces and behind the metal rod.

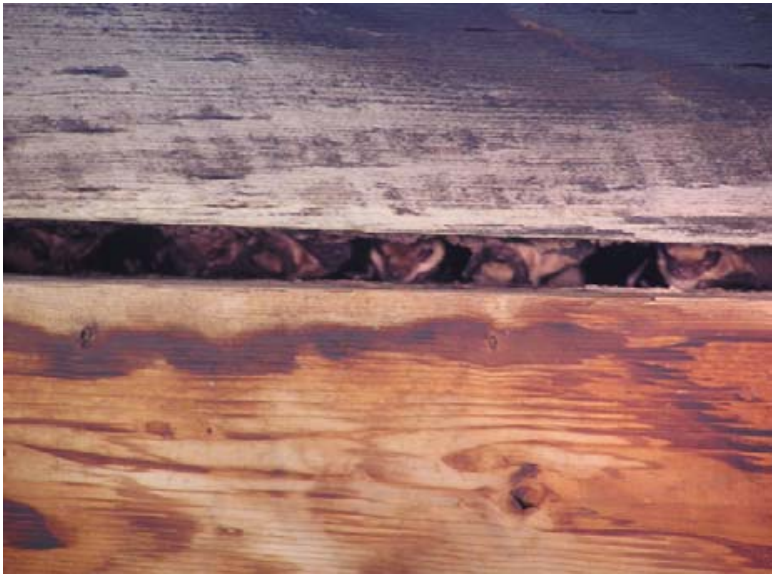

Figure 8. Maternity colony of Big Brown Bats at bridge shown in Figure 7.

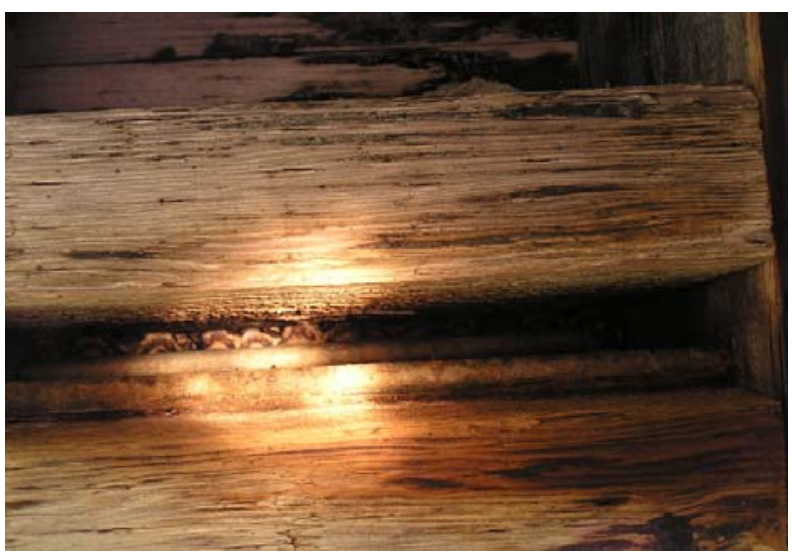

Figure 10. Little Brown Myotis maternity colony in a site like that in Figure 9, along a frontage road east of Pompeys Pillar. 


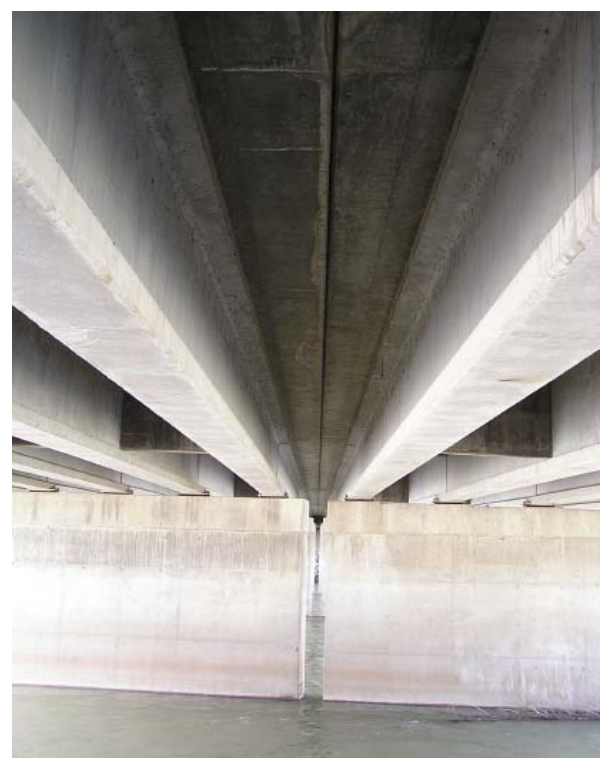

Figure 11. Day roost site between US 87 bridge spans, Yellowstone River in Billings, MT.

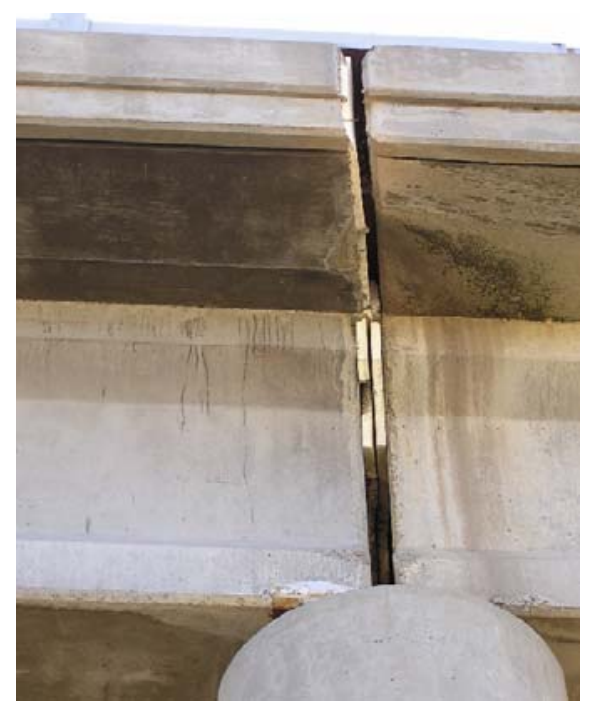

Figure 13. Day roost of Big Brown Bats in expansion joint between two concrete sections of State 306 crossing I-90; bats above the fill material.

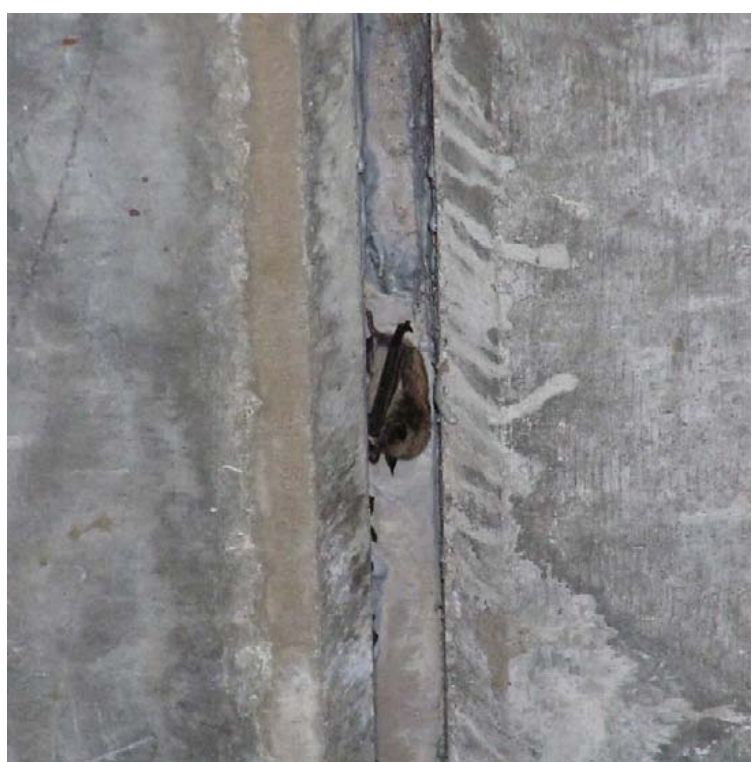

Figure 12. Occupied day roost between abutting US 87 bridge spans shown in Figure 11.

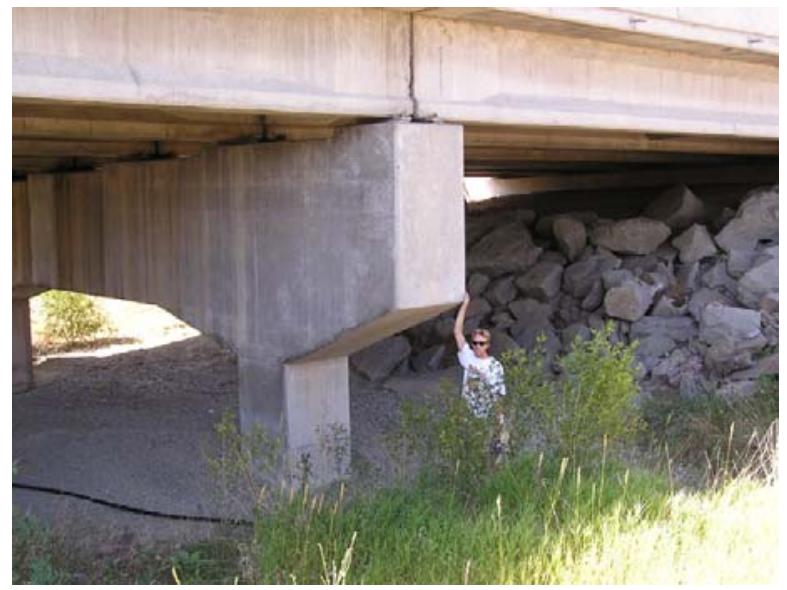

Figure 14. Day roost of Big Brown Bats in the expansion joint between two concrete sections of I-90, west bound. 


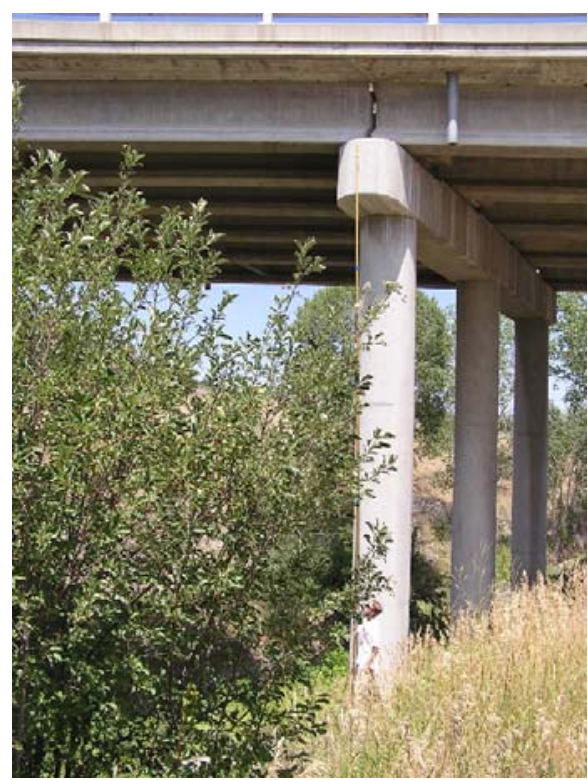

Figure 15. Big Brown Bat day roost in expansion joint of I-90, west bound, $9.8 \mathrm{~m}(32.2 \mathrm{ft})$ above ground.

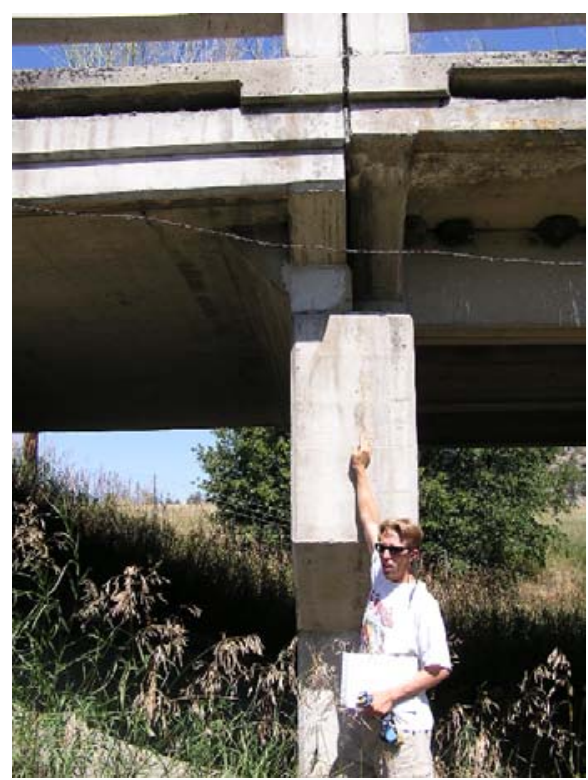

Figure 16. Big Brown Bat day roost in expansion joint of concrete bridge on frontage road west of Columbus. 
Table 7. Bat occupancy (adults) at day roosts discovered in 2003 in south-central Montana highway structures.

\begin{tabular}{|c|c|c|c|c|c|}
\hline County & MDT Bridge No. & $\begin{array}{c}\text { Bridge } \\
\text { Material }\end{array}$ & $\begin{array}{l}\text { Bridge } \\
\text { Design }\end{array}$ & Date & $\begin{array}{c}\text { Bat } \\
\text { Species }^{\mathrm{a}} \\
\end{array}$ \\
\hline Stillwater & $\begin{array}{c}\text { P00078043+05911 } \\
\text { maternity colony }\end{array}$ & wood & girder & $\begin{array}{r}16 \text { Jul } \\
17 \text { Jul } \\
18 \text { Jul } \\
18 \text { Aug } \\
9 \text { Sep } \\
16 \text { Sep }\end{array}$ & $\begin{array}{l}\text { LACI (1), EPFU (12) } \\
\text { EPFU (15) } \\
\text { EPFU (15) } \\
\text { EPFU (6) } \\
\text { EPFU (14) } \\
\text { no bats }\end{array}$ \\
\hline Stillwater & S00306002+02901 & concrete & T-beam & $\begin{array}{r}17 \mathrm{Jul} \\
18 \mathrm{Aug} \\
9 \mathrm{Sep}\end{array}$ & $\begin{array}{l}\text { EPFU (8) } \\
\text { EPFU (3) } \\
\text { no bats }\end{array}$ \\
\hline Stillwater & I00090400+03661 & concrete & T-beam & $\begin{array}{r}18 \mathrm{Jul} \\
18 \mathrm{Aug} \\
9 \mathrm{Sep} \\
16 \mathrm{Sep} \\
\end{array}$ & $\begin{array}{l}\text { EPFU (1) } \\
\text { EPFU (4) } \\
\text { EPFU (1) } \\
\text { EPFU (1) }\end{array}$ \\
\hline Stillwater & L48244008+04001 & concrete & T-beam & $\begin{array}{r}18 \mathrm{Jul} \\
18 \text { Aug } \\
9 \text { Sep }\end{array}$ & $\begin{array}{l}\text { EPFU (1) } \\
\text { no bats } \\
\text { no bats }\end{array}$ \\
\hline Stillwater & $\mathrm{I} 00090414+02351$ & concrete & T-beam & $\begin{array}{r}18 \mathrm{Jul} \\
18 \mathrm{Aug} \\
9 \mathrm{Sep} \\
\end{array}$ & $\begin{array}{l}\text { no bats } \\
\text { EPFU (1) } \\
\text { EPFU (2) }\end{array}$ \\
\hline Stillwater & I00090414+02352 & concrete & T-beam & $\begin{array}{r}18 \mathrm{Jul} \\
18 \mathrm{Aug} \\
9 \mathrm{Sep} \\
\end{array}$ & $\begin{array}{l}\text { EPFU (4) } \\
\text { no bats } \\
\text { no bats }\end{array}$ \\
\hline Yellowstone & P00016000+06721 & concrete & T-beam & $\begin{array}{l}17 \text { Jul } \\
19 \text { Aug } \\
13 \text { Sep } \\
16 \text { Sep } \\
\end{array}$ & $\begin{array}{l}\text { EPFU (2) } \\
\text { EPFU (1) } \\
\text { EPFU (2) } \\
\text { EPFU (2) }\end{array}$ \\
\hline Yellowstone & L56788029+05001 & wood & girder & $\begin{array}{r}18 \text { Jul } \\
19 \text { Jul } \\
13 \text { Sep } \\
16 \text { Sep } \\
\end{array}$ & $\begin{array}{l}\text { EPFU (1) } \\
\text { no bats } \\
\text { MYCI (1) } \\
\text { MYCI (1) }\end{array}$ \\
\hline Yellowstone & $\begin{array}{c}\text { L56788035+00001 } \\
\text { maternity colony }\end{array}$ & wood & girder & $\begin{array}{r}18 \mathrm{Jul} \\
19 \mathrm{Jul} \\
19 \mathrm{Aug} \\
13 \mathrm{Sep} \\
16 \mathrm{Sep}\end{array}$ & $\begin{array}{l}\text { MYLU (ca. 39) } \\
\text { MYLU (ca. 87) } \\
\text { MYLU (ca. 26) } \\
\text { MYLU (1) } \\
\text { MYCI (1) }\end{array}$ \\
\hline Yellowstone & $\begin{array}{c}\text { L56788036+05001 } \\
\text { maternity colony }\end{array}$ & wood & girder & $\begin{array}{r}18 \text { Jul } \\
19 \mathrm{Jul} \\
19 \text { Aug } \\
13 \mathrm{Sep} \\
\end{array}$ & $\begin{array}{l}\text { EPFU (ca. 32) } \\
\text { EPFU (ca. 45) } \\
\text { EPFU (7) } \\
\text { EPFU (1) }\end{array}$ \\
\hline Yellowstone & L56788010+03001 & wood & girder & $\begin{array}{r}19 \mathrm{Jul} \\
13 \mathrm{Sep} \\
\end{array}$ & $\begin{array}{l}\text { EPFU (1) } \\
\text { no bats }\end{array}$ \\
\hline Yellowstone & $\begin{array}{c}\text { S00532010+06381 } \\
\text { maternity colony }\end{array}$ & concrete & box-beam & $\begin{array}{l}19 \text { Aug } \\
12 \text { Sep }\end{array}$ & $\begin{array}{l}\text { MYLU (11) } \\
\text { no bats }\end{array}$ \\
\hline
\end{tabular}

${ }^{a}$ EPFU: Eptesicus fuscus (Big Brown Bat), LACI: Lasiurus cinereus (Hoary Bat), MYCI: Myotis ciliolabrum (Western Small-footed Myotis), MYLU: Myotis lucifugus (Little Brown Myotis). 
Table 8. Bat occupancy (adults) in 2004 at the day roosts discovered in 2003 in south-central Montana highway structures.

\begin{tabular}{|c|c|c|c|c|c|}
\hline County & MDT Bridge No. & $\begin{array}{c}\text { Bridge } \\
\text { Material }\end{array}$ & $\begin{array}{l}\text { Bridge } \\
\text { Design }\end{array}$ & Date & $\begin{array}{c}\text { Bat } \\
\text { Species }^{\mathbf{a}}\end{array}$ \\
\hline Stillwater & $\begin{array}{c}\text { P00078043+05911 } \\
\text { maternity colony }\end{array}$ & wood & girder & $\begin{array}{r}7 \text { Jun } \\
21 \text { Jul } \\
26 \text { Aug } \\
1 \text { Oct }\end{array}$ & $\begin{array}{l}\text { EPFU (12) } \\
\text { EPFU (12) } \\
\text { EPFU (4) } \\
\text { EPFU (2) }\end{array}$ \\
\hline Stillwater & S00306002+02901 & concrete & T-beam & $\begin{array}{r}10 \text { Jun } \\
21 \mathrm{Jul} \\
26 \text { Aug } \\
1 \text { Oct }\end{array}$ & $\begin{array}{l}\text { no bats } \\
\text { EPFU (4) } \\
\text { no bats } \\
\text { no bats }\end{array}$ \\
\hline Stillwater & I00090400+03661 & concrete & T-beam & $\begin{array}{r}10 \mathrm{Jun} \\
21 \mathrm{Jul} \\
26 \text { Aug } \\
1 \text { Oct }\end{array}$ & $\begin{array}{l}\text { EPFU (1) } \\
\text { EPFU (1) } \\
\text { EPFU (17) } \\
\text { no bats }\end{array}$ \\
\hline Stillwater & L48244008+04001 & concrete & T-beam & $\begin{array}{r}10 \text { Jun } \\
21 \mathrm{Jul} \\
26 \text { Aug } \\
1 \text { Oct }\end{array}$ & $\begin{array}{l}\text { no bats } \\
\text { no bats } \\
\text { no bats } \\
\text { no bats }\end{array}$ \\
\hline Stillwater & I00090414+02351 & concrete & T-beam & $\begin{array}{r}10 \text { Jun } \\
21 \mathrm{Jul} \\
26 \text { Aug } \\
1 \text { Oct }\end{array}$ & $\begin{array}{l}\text { no bats } \\
\text { no bats } \\
\text { no bats } \\
\text { no bats }\end{array}$ \\
\hline Stillwater & I00090414+02352 & concrete & T-beam & $\begin{array}{r}10 \text { Jun } \\
21 \mathrm{Jul} \\
26 \text { Aug } \\
1 \text { Oct }\end{array}$ & $\begin{array}{l}\text { no bats } \\
\text { EPFU (1) } \\
\text { EPFU (1) } \\
\text { no bats }\end{array}$ \\
\hline Yellowstone & P00016000+06721 & concrete & T-beam & $\begin{array}{r}22 \mathrm{Jul} \\
27 \text { Aug } \\
1 \text { Oct }\end{array}$ & $\begin{array}{l}\text { EPFU (1), MYLU (2) } \\
\text { EPFU (1) } \\
\text { MYLU (1) }\end{array}$ \\
\hline Yellowstone & L56788029+05001 & wood & girder & $\begin{array}{r}7 \text { Jun } \\
21 \mathrm{Jul} \\
26 \text { Aug } \\
1 \text { Oct }\end{array}$ & $\begin{array}{l}\text { no bats } \\
\text { MYLU (1) } \\
\text { no bats } \\
\text { no bats }\end{array}$ \\
\hline Yellowstone & $\begin{array}{c}\text { L56788035+00001 } \\
\text { maternity colony }\end{array}$ & wood & girder & $\begin{array}{r}7 \text { Jun } \\
21 \mathrm{Jul} \\
26 \text { Aug } \\
1 \text { Oct }\end{array}$ & $\begin{array}{l}\text { MYLU (ca. 130) } \\
\text { MYLU (ca. 125) } \\
\text { MYLU (16) } \\
\text { no bats }\end{array}$ \\
\hline Yellowstone & $\begin{array}{c}\text { L56788036+05001 } \\
\text { maternity colony }\end{array}$ & wood & girder & $\begin{array}{r}7 \text { Jun } \\
21 \mathrm{Jul} \\
26 \text { Aug } \\
1 \text { Oct } \\
\end{array}$ & $\begin{array}{l}\text { EPFU (ca. 36) } \\
\text { EPFU (ca. 72) } \\
\text { no bats } \\
\text { no bats }\end{array}$ \\
\hline Yellowstone & L56788010+03001 & wood & girder & $\begin{array}{r}22 \mathrm{Jul} \\
27 \text { Aug } \\
1 \text { Oct }\end{array}$ & $\begin{array}{l}\text { no bats } \\
\text { no bats } \\
\text { no bats }\end{array}$ \\
\hline Yellowstone & $\begin{array}{c}\text { S00532010+06381 } \\
\text { maternity colony }\end{array}$ & concrete & box-beam & $\begin{array}{r}22 \mathrm{Jul} \\
27 \text { Aug } \\
1 \text { Oct }\end{array}$ & $\begin{array}{l}\text { MYLU (ca. 78) } \\
\text { MYLU (14) } \\
\text { MYLU (1) }\end{array}$ \\
\hline
\end{tabular}

${ }^{a}$ EPFU: Eptesicus fuscus (Big Brown Bat), MYLU: Myotis lucifugus (Little Brown Myotis). 
the exception of a solitary adult female Hoary Bat with at least two young observed by us in 2003 at one bridge near a maternity colony of Big Brown Bats (Table 7). Lone Western Smallfooted Myotis appeared at two bridges in mid-September, and probably were dispersing individuals.

Eight (67\%) of the twelve day roosts in 2003, and seven (78\%) of the nine used day roosts in 2004, were occupied on more than one visit, spanning at least one month in each case (Tables 78). There was one case of probable day-roost switching between adjacent bridges on I-90; four Big Brown Bats were present in the west-bound bridge only on the initial survey, and one or two individuals of the same species were present in the neighboring east-bound bridge only on subsequent visits. In 2004 there was no evidence of day roost use at three of the day roost structures of 2003; none of these three were occupied by more than two bats the first year of the survey.

\section{Maternity Colonies:}

Of the 12 day-roosts, four were confirmed maternity colonies (two Big Brown Bat, two Little Brown Myotis), three in wood bridges and one in concrete (Tables 7-8). One of these (a colony of Little Brown Myotis in a concrete span) was found too late in 2003 to determine that it was a maternity colony; this status was confirmed in 2004. Number of adult females estimated at each of the maternity colonies was relatively constant each year (the smallest colony ranged from 1415 females, the largest 87-130 females). Maternity colonies were generally occupied from early June (probably late May) to late August, with a few bats still present at some through midSeptember each year and into the first part of October. Small pups were noted at these colonies by mid-July each year. 


\section{DISCUSSION}

\section{Bridge Use in Montana}

Use of highway structures by roosting bats was widespread in the three-county area of southcentral Montana (Figure 1): $60 \%$ of the 130 structures we inspected in summer 2003 were used for roosting (night, day, or both), with $9.2 \%$ specifically being occupied day roosts (Table 1 , Appendix 1). Both values exceeded the results of a Bat Conservation International (BCI) survey in 25 southern and western states (7); 38.2\% of 2421 structures were identified as roost sites, and $8.7 \%$ specifically as day roosts. For states in the northern Rocky Mountain region that were surveyed by BCI, $36.7 \%$ of 30 structures in Idaho and $74.4 \%$ of 121 structures in Wyoming were used by bats; occupied day roosts represented $6.7 \%$ and $2.5 \%$ of the respective state samples. Thus, our results contradict the initial assumption of the BCI survey (7) that highway structures in Montana generally are not warm enough to meet bat needs.

The influence of the surrounding landscape on structure use by bats has been little studied. In our study area, the immediate and nearby landscape context of the surrounding $3.0 \mathrm{~km}(1.86$ miles) radius appeared to have little influence on which structures were used by bats and the intensity of that use (Tables 2-5). Only percent forest cover showed a significant pattern, being greater near bridges used as roosts and greatest around day roosts (Table 3). Forested landscapes tend to support a greater abundance of arthropod prey and provide additional habitat for night roosting $(27,28)$, thus its increased prevalence around night and day roosts might be expected. All of the day roosts we found were within $4.5 \mathrm{~km}$ (3 miles) of the riparian corridor of the Yellowstone River, with the exception of one on Canyon Creek (a tributary of the Yellowstone River) $6.3 \mathrm{~km}$ (4.5 miles) distant. The BCI survey found that suitable highway structures in open plains were rarely used (7), which is consistent with our results. However, forest cover around some of our day roosts was very low $(0-10 \%)$, and forest cover was greatest around some individual non-used structures and night roosts. Thus, increased forest cover around highway structures used by bats is a trend, but other criteria appear to be equally or more important in determining use of specific structures.

Bats used a variety of highway structures in south-central Montana for roosts, including culverts and bridges of various designs; we did not adequately quantify culvert use during our survey because of a small sample size (Appendix 1). Nevertheless, it is our impression that culverts would probably be used most as night roosts, and then only under unusual circumstances, because they provided few sites for bats to perch, other than in old swallow nests.

Bats used concrete, steel, and wood bridges as night roosts in our study area, and concrete and wood bridges for day roosts (Table 6). Night roost sites often were on the vertical faces of girders on the underside of bridges where girders abut the deck, which is typical for bats in many regions $(7,12,14,29,30)$. Specific locations on girders are probably determined by the spatial availability of disconformities on the girder surface from which bats can hang, as well as the relative protection and thermal properties provided by the site. We did not measure thermal properties of highway structures, so we are unable to determine how used bridges or sites may have differed in this regard from unused ones in this region of Montana. Flat bottom concrete bridges ("slabs") are used less frequently than other concrete designs $(7,30)$, as we also found in south-central Montana, because they offer less protected roosts and few sites on which to cling. 
Day roosts in our study area (Tables 7-8) were in narrow vertical spaces and at greater minimum heights above ground than night roosts. Day roosts generally are in more confined and protected locations than night roosts $(7,10,13,15,30)$. Five of seven we found were in expansion joints of concrete bridges near the edge of the deck where cushion material had eroded (Figures 12-15). Other sites in concrete bridges included the space on the underside of a box-beam bridge, and the space between two abutting cast-in-place T-beam bridges. Concrete bridges are the kind of structure most used by day-roosting bats because of the thermal properties of concrete and the protection provided by potential roost sites in them (7), which include all of the roosting sites we discovered during our survey. Thus, this aspect of our results is consistent with findings from other regions of North America.

Three of four maternity colonies we found were in wood bridges (Tables 7-8), either between adjacent wooden girders running parallel to the deck (Figures 6-8), similar to the railroad bridge illustrated in Davis and Cockrum (10), or between two braces supporting bolted bridge railings (Figures 9-10). At maternity roosts in the latter type of site, more than one brace location was occupied concurrently (usually 5-6 out of 12). Roosting crevices provided by the wood bridges were similar to those in bat boxes $(7,31,32)$, and may simulate preferred spaces bats use in trees and buildings. Wood bridges are used in other regions, but usually at relatively low frequency for reasons yet to be determined. Adam and Hayes (14) suggested that treatment of the wood with creosote may deter bats from using them, but this did not appear to be the case in southcentral Montana.

There were variable levels of fidelity within and between years to bridges used as day roosts. The four maternity roosts were occupied both years of the survey, and generally were used for the greatest duration each summer: June through August or September (Tables 7-8). Our surveys of day roosts used by bachelors and/or non-reproductive females showed a smaller degree of between-year fidelity (we documented use both years at five of eight of these), and within-year use of some of these tended to be confined to one or two months (July and August, or August and September). Strong fidelity by females to maternity roosts may benefit them in raising their young, through a decrease in thermoregulatory costs as a result of group living (33).

Four species of bat were found in day roosts during our survey: Big Brown Bat, Hoary Bat, Little Brown Myotis, and Western Small-footed Myotis. None of these are Montana Animal Species of Concern (18), but two that are on the Animal Species of Concern list, Townsend's Big-eared Bat (Corynorhinus townsendii) and Pallid Bat (Antrozoas pallidus), occur in south-central Montana $(19,20,21)$ and sometimes use bridges $(7,10,12,14)$. Pallid Bats often use bridges for day and night roosts $(10,29)$ but appear to be very limited in distribution in Montana and relatively rare. Frequency of bridge use by Townsend's Big-eared Bat is apparently low throughout its range $(7,12,14)$; none of 105 bridges surveyed in Utah were used by this species during a study of its roosting affinities 34). Nevertheless, occasional use of bridges by Townsend's Big-eared Bat and Pallid Bat at some localities in Montana should be anticipated.

All of the species we found during our survey, with the exception of the Hoary Bat, have been documented roosting in bridges in other regions $(7,10,12,13,14,29)$. Day roosts occupied by less than five Big Brown Bats and Little Brown Myotis were probably bachelor males or non- 
reproductive females $(35,36)$. The single Western Small-footed Myotis we noted at two bridges in 2003 were likely dispersing from other sites (37), as they appear to use bridges only infrequently and were not detected by us prior to September. The late-summer appearance of 17 Big Brown Bats at a day roost previously used by a single bat was also likely a dispersing group, possibly from a maternity colony. However, without knowing the age or sex composition of this group this remains speculation.

Our encounter of a female Hoary Bat with two young in a wood bridge in 2003 is apparently the first documented case of bridge use by this species $(7,12,38,39)$. Hoary Bats usually roost in tree foliage $(40,41)$ and only rarely use man-made structures. Regular but low frequency use of bridges by Hoary Bats would be difficult to detect, if it occurs, because it is a solitary roosting species that often switches roost sites (33). That it happened to use a wood bridge as a temporary day roost, the man-made structure most like a tree cavity, may be coincidental.

\section{Bridge Management for Bats}

Two bat species on the state Animal Species of Concern list (18), Townsend's Big-eared Bat and Pallid Bat, occur in south-central Montana and have the potential to roost in highway structures within their ranges in the state. A third bat species not yet documented in the south-central region of Montana $(17,42)$ but on the Animal Species of Concern list, Fringed Myotis (Myotis thysanoides), is known to roost in bridges where it occurs in other states $(7,14)$.

\section{Mitigation and Protection:}

Because use of highway structures by bats is relatively widespread and common in south-central Montana (Figure 1), measures to mitigate disturbance or removal of roosts, even for common species, should be considered when replacing or repairing structures. State Departments of Transportation in Texas and California have developed management policies for protecting and enhancing bridge roosts, demonstrating proactive commitment to the environment, aiding farmers, and providing positive publicity at little cost to taxpayers $(2,7)$. Similar policies in Montana could provide the same benefits.

At a minimum, effort should be made to protect day roost structures, especially those harboring maternity colonies, because fidelity to these sites is high (33), and their loss could be detrimental to local breeding populations. Our survey indicates that day roosts in Montana bridges may be most prevalent along or near riparian river corridors. We suggest surveying all structures scheduled for repair or replacement, to determine the evidence for bat presence or absence prior to the onset of construction activity. For structures harboring maternity colonies, schedule construction to begin prior to early summer re-occupancy (late May) or following late-summer dispersal from the roost (late August or early September); maintenance conducted between midOctober and early April will minimize disturbance. Before working near known roosts, maintenance crews should be encouraged to avoid disturbing the bats as much as possible, and taught not to handle them. These procedures will minimize the direct exposure of crews to bats and eliminate the possibility of personnel being bitten, which would then necessitate postexposure rabies treatment.

Most maternity roosts in south-central Montana will probably be in wooden bridges, but concrete box-beam designs will also support maternity colonies, and expansion joints of cast-in-place T- 
beam structures should be examined (both on the underside of the deck and near the deck edge), as these sites have been used by maternity colonies in other regions (e.g., 10). Slab designs with no expansion joints, and steel-girder bridges, are the structures least likely to be used for dayroosting and maternity roosts.

When bridges are scheduled for replacement, consider using a replacement design that is most favored by bats (see discussion in 7). Preferred designs include in their structure slots where bats can roost in protection and relative isolation from disturbance, either in open expansion joints (with overhead protection) or in the parallel slots of box-beam designs; spaces need to be $3 \mathrm{~cm}$ (1.25 inches) wide and 20-30 cm (8-12 inches) or more deep. If such replacement bridge designs are not practical, structures can be fitted (or retrofitted) on the underside with roosting boxes $(7$, 32), similar to regular bat boxes and serving to house displaced maternity colonies (31).

\section{Excluding Bats from Day Roost Structures:}

Most small bat colonies in bridges pose no threat to humans (7), however in some circumstances it may be determined necessary to exclude bats from a highway structure. Excluding bats from day roosts allows bats to depart unharmed but not reenter roosts. In circumstances where maintenance must be done while bats are present, exclusion techniques reduce the potential for workers to come into contact with bats. The methods discussed by Bat Conservation International (7) are the ones we recommend for use in Montana.

The BCI methods, illustrated in their publication (7), are summarized as follows. To conduct an effective exclusion, all primary exit points first must be identified and marked. All other escape routes greater than $0.6 \mathrm{~cm}(0.25$ inches $)$ are sealed with a suitable substance, such as wood, backer rod, expanding foam, or caulk. Access to unused portions of long crevices can also be filled with these substances. Care should be taken to avoid sealing bats into roosts. One-way valves, constructed of wire-mesh cones, PVC, or clear plastic sheeting, are attached over each roost exit point to prevent re-entry; one-way valves made of clear plastic sheeting are effective for long crevices, wire cones and PVC are effective for discrete exit holes. Once bats have been excluded, roost spaces can be permanently filled with a suitable substance. For the day roosts we found in concrete deck expansion joints or elongated slots under the deck (see Figures 11-16), expanding foam may be the easiest substance to use for permanent closure, but weathering of this material may require relatively frequent replacement in some circumstances. 


\section{REFERENCES CITED}

1. Fenton, M. B. 1997. "Science and the Conservation of Bats." Journal of Mammalogy 78:114.

2. Pierson, E. D. 1998. "Tall Trees, Deep Holes, and Scarred Landscapes: Conservation Biology of North American Bats." Pp. 309-325, In Bat biology and conservation (T. H. Kunz and P. A. Racey, eds.). Smithsonian Institution Press, Washington, DC. 365 pp.

3. O'Shea, T. J., M. A. Bogan, and L. E. Ellison. 2003. "Monitoring Trends in Bat Populations of the United States and Territories: Status of the Science and Recommendations for the Future.” Wildlife Society Bulletin 31:16-29.

4. Humphrey, S. R. 1975. "Nursery Roosts and Community Diversity of Nearctic Bats." Journal of Mammalogy 56:321-346.

5. Dobkin, D. S., R. D. Gettinger, and M. G. Gerdes. 1995. "Springtime Movements, Roost Use, and Foraging Activity of Townsend's Big-eared Bat (Plecotus townsendii) in Central Oregon." Great Basin Naturalist 55:315-321.

6. Sheffield, S. R., J. H. Shaw, G. A. Heidt, and L. R. McClenaghan. 1992. "Guidelines for the Protection of Bat Roosts.” Journal of Mammalogy 73:707-710.

7. Keeley, B. W., and M. D. Tuttle. 1999. "Bats in American Bridges." Resource Publication No. 4. Bat Conservation International. Austin, TX. 41 p.

8. Hendricks, P., D. L. Genter, and S. Martinez. 2000. "Bats of Azure Cave and the Little Rocky Mountains, Montana." Canadian Field-Naturalist 114:89-97.

9. Hendricks, P., and D. Kampwerth. 2001. "Roost Environments for Bats Using Abandoned Mines in Southwestern Montana: a Preliminary Assessment." Report to the U.S. Bureau of Land Management. Montana Natural Heritage Program, Helena. 19 pp.

10. Davis, R., and E. L. Cockrum. 1963. "Bridges Utilized as Day-roosts by Bats." Journal of Mammalogy 44:428-430.

11. Perlmeter, S. I. 1996. "Bats and Bridges: Patterns of Night Roost Activity in the Willamette National Forest.” Pp. 132-150. In: R. M. Barclay and R. M. Brigham (eds.). Bats and forests: proceedings of the Victoria Symposium. Ministry of Forests Research Program Working Paper 23/1996. Victoria, BC. 292 p.

12. Pierson, E. D., W. E. Rainey, and R. M. Miller. 1996. "Night Roost Sampling: a Window on the Forest Bat Community in Northern California." Pp. 151-163. In: R. M. Barclay and R. M. Brigham (eds.). Bats and forests: proceedings of the Victoria Symposium. Ministry of Forests Research Program Working Paper 23/1996. Victoria, BC. 292 p. 
13. Gore, J. A., and J. A. Hovis. 1997 . "Summer Use of Highway Bridges by Roosting Bats in North Florida (abstract)." Pp. 31-32, In $27^{\text {th }}$ Annual North American Symposium on bat research: program and abstracts.

14. Adam, M. D., and J. P. Hayes. 2000. "Use of Bridges as Night Roosts by Bats in the Oregon Coast Range." Journal of Mammalogy 81:402-407.

15. Sgro, M. P., and K. T. Wilkins. 2003. "Roosting Behavior of the Mexican Free-tailed Bat (Tadarida brasiliensis) in a highway overpass." Western North American Naturalist 63:366-373.

16. Hendricks, P. 2000. "Bat Survey Along the Norris-Madison Junction Road Corridor, Yellowstone National Park, Wyoming, 1999." Montana Natural Heritage Program. Helena, MT. 15 pp.

17. Foresman, K. R. 2001. The Wild Mammals of Montana. American Society of Mammalogists, Special Publication No. 12. 278 pp.

18. Carlson, J. (Coordinator, Montana Animal Species of Concern Committee). 2003. "Montana Animal Species of Concern." Montana Natural Heritage Program and Montana Fish, Wildlife and Parks, Helena, Montana. 14 pp.

19. Swenson, J. E., and J. C. Bent. 1977. "The Bats of Yellowstone County, Southcentral Montana." Proceedings of the Montana Academy of Sciences 37:82-84.

20. Shryer, J. and D. L. Flath. 1980. "First Record of the Pallid Bat (Antrozoas pallidus) From Montana." Great Basin Naturalist 40:115.

21. Worthington, D. J. 1991. "Abundance and Distribution of Bats in the Pryor Mountains of South Central Montana and Northeastern Wyoming." Montana Natural Heritage Program. Helena, MT. 23 pp.

22. Hendricks, P., and J. Carlson. 2001. "Bat Use of Abandoned Mines in the Pryor Mountains." Report to the Montana Department of Environmental Quality, Mine Waste Cleanup Bureau. Montana Natural Heritage Program, Helena. 8 pp.

23. Nesser, J. A., G. L. Ford, C. L. Maynard, ans D. S. Page-Dumroese. 1997. "Ecological Units of the Northern Region: Subsections.” General Technical Report INT-GTR-369. Ogden, UT: U.S. Department of Agriculture, Forest Service, Intermountain Research Station. 88 pp.

24. van Zyll de Jong, C. G. 1985. Handbook of Canadian Mammals. 2. Bats. National Museum of Natural Sciences. Ottawa, ON. 212 p.

25. Nagorsen, D. W., and R. M. Brigham. 1993. Bats of British Columbia. UBC Press. Vancouver, BC. 164 p. 
26. Sokal, R. R., and F. J. Rohlf. 1981. Biometry, second edition. W. H. Freeman. San Francisco, CA.859 pp.

27. Wunder, L., and A. B. Carey. 1996. "Use of the Forest Canopy by Bats." Northwest Science 70:79-85.

28. Grindal, S. D., and R. M. Brigham. 1998. "Short-term Effects of Small-scale Habitat Disturbance on Activity by Insectivorous Bats." Journal of Wildlife Management 62:996-1003.

29. Brigham, R. M., M. J. Sarell, and C. G. Harris. 1990. "Roosting of Northern Flicker (Colaptes auratus) Under a Concrete Bridge.” Northwestern Naturalist 71:52-53.

30. Lewis, S. E. 1994. "Night Roosting Ecology of Pallid Bats (Antrozoas pallidus) in Oregon." American Midland Naturalist 132:219-226.

31. Brittingham, M. C., and L. M. Williams. 2000. "Bat Boxes as Alternative Roosts for Displaced Bat Maternity Colonies.” Wildlife Society Bulletin 28:197-207.

32. Arnett, E. B., and J. P. Hayes. 2000. "Bat Use of Roosting Boxes Installed Under Flatbottom Bridges in Western Oregon." Wildlife Society Bulletin 28:890-894.

33. Lewis, S. E. 1995. "Roost Fidelity of Bats: a Review.” Journal of Mammalogy 76:481-496.

34. Sherwin, R. E., D. Strickland, and D. S. Rogers. 2000. "Roosting Affinities of Townsend's Big-eared Bat (Corynorhinus townsendii) in Northern Utah." Journal of Mammalogy 81:939-947.

35. Fenton, M. B., and R. M. R. Barclay. 1980. "Myotis lucifugus.” Mammalian Species 142:18.

36. Kurts, A., and R. H. Baker. 1990. “Eptesicus fuscus.” Mammalian Species 356:1-10.

37. Holloway, G. L., and R. M. R. Barclay. 2001. "Myotis ciliolabrum.” Mammalian Species 670:1-5.

38. Shump, K. A., Jr., and A. U. Shump. 1982. "Lasiurus cinereus.” Mammalian Species 185:1-5.

39. Hendricks, P., J. Johnson, S. Lenard, and C. Currier. 2004. "Use of a Bridge for Day Roosting by the Hoary Bat, Lasiurus cinereus." Canadian Field-Naturalist 118:in press.

40. Constantine, D. G. 1966. "Ecological Observations on Lasiurine Bats in Iowa." Journal of Mammalogy 47:34-41. 
41. Barbour, R. W, and W. H. Davis. 1969. Bats of America. University Press of Kentucky. Lexington, KY. $286 \mathrm{p}$.

42. Hoffmann, R. S., D. L. Pattie, and J. F. Bell. 1969. "The Distribution of Some Mammals in Montana. II. Bats." Journal of Mammalogy 50:737-741. 


\section{APPENDIX 1}

\section{HIGHWAY STRUCTURES IN SOUTH-CENTRAL MONTANA}

EXAMINED FOR USE BY BATS DURING 2003 
Appendix 1. Highway structures examined during summer 2003 for evidence of use by bats. When more than one bridge material is used, the type listed is for the girders. Bat numbers at day roosts are for the initial survey date (see Table 7).

\begin{tabular}{|c|c|c|c|c|c|c|c|c|}
\hline County & MDT Bridge No. & $\begin{array}{c}\text { GPS Lati-Long } \\
(\mathrm{N} ; \mathrm{W})\end{array}$ & $\begin{array}{l}\text { Elevation } \\
\text { (m) }\end{array}$ & Date & $\begin{array}{c}\text { Bridge } \\
\text { Material }\end{array}$ & $\begin{array}{l}\text { Bridge } \\
\text { Design }\end{array}$ & $\begin{array}{l}\text { Bat } \\
\text { Use }^{\mathbf{a}}\end{array}$ & $\begin{array}{c}\text { Bat } \\
\text { Species }\end{array}$ \\
\hline Carbon & P00004004+02201 & $45.05525 ; 108.65604$ & 1336 & $14 \mathrm{Jul}$ & steel & culvert & 0 & \\
\hline Carbon & P00004012+00631 & $45.13152 ; 108.76762$ & 1295 & $15 \mathrm{Jul}$ & steel & I-beam & 1 & $?$ \\
\hline Carbon & US310 unlisted & $45.18046 ; 108.84502$ & 1274 & $15 \mathrm{Jul}$ & steel & culvert & 0 & \\
\hline Carbon & US310 unlisted & $45.19371 ; 108.85675$ & 1195 & $15 \mathrm{Jul}$ & steel & culvert & 1 & $?$ \\
\hline Carbon & P00004023+05561 & $45.26156 ; 108.90916$ & 1138 & $15 \mathrm{Jul}$ & concrete & T-beam & 1 & $?$ \\
\hline Carbon & $\mathrm{P} 00004023+07461$ & $45.26359 ; 108.91045$ & 1131 & $15 \mathrm{Jul}$ & concrete & T-beam & 1 & $?$ \\
\hline Carbon & P00072014+04031 & $45.19009 ; 108.98440$ & 1154 & $15 \mathrm{Jul}$ & steel & I-beam & 0 & \\
\hline Carbon & P00072013+07141 & $45.17996 ; 108.99243$ & 1152 & $15 \mathrm{Jul}$ & wood & girder & 0 & \\
\hline Carbon & P00072011+09041 & $45.15705 ; 109.00567$ & 1168 & $15 \mathrm{Jul}$ & steel & I-beam & 0 & \\
\hline Carbon & P00072005+03821 & $45.07513 ; 109.03509$ & 1206 & $15 \mathrm{Jul}$ & concrete & T-beam & 1 & $?$ \\
\hline Carbon & $\mathrm{P} 00028059+04791$ & $45.08697 ; 109.36644$ & 2028 & $15 \mathrm{Jul}$ & concrete & T-beam & 1 & $?$ \\
\hline Carbon & P00078019+08491 & $45.35050 ; 109.49554$ & 1539 & $16 \mathrm{Jul}$ & concrete & T-beam & 1 & $?$ \\
\hline Carbon & P00078012+08701 & $45.30586 ; 109.38893$ & 1511 & $16 \mathrm{Jul}$ & wood & girder & 0 & \\
\hline Carbon & P00004029+01101 & $45.33850 ; 108.91652$ & 1099 & $16 \mathrm{Jul}$ & steel & culvert & 0 & \\
\hline Carbon & P00004042+04541 & $45.51772 ; 108.86250$ & 1063 & $16 \mathrm{Jul}$ & concrete & T-beam & 1 & ${ }^{\mathrm{c}} \mathrm{MYLU}(1)$ \\
\hline Stillwater & P00078026+02021 & $45.43545 ; 109.46764$ & 1376 & $16 \mathrm{Jul}$ & concrete & T-beam & 1 & $?$ \\
\hline Stillwater & $\mathrm{P} 00078030+01551$ & $45.48324 ; 109.45156$ & 1301 & $16 \mathrm{Jul}$ & steel & I-beam & 0 & \\
\hline Stillwater & $\mathrm{P} 00078031+00361$ & $45.49560 ; 109.44997$ & 1271 & $16 \mathrm{Jul}$ & wood & girder & 0 & \\
\hline Stillwater & P00078038+09111 & $45.53730 ; 109.41187$ & 1203 & $16 \mathrm{Jul}$ & wood & girder & 0 & \\
\hline Stillwater & $\mathrm{P} 00078039+06001$ & $45.56901 ; 109.33257$ & 1163 & $16 \mathrm{Jul}$ & steel & I-beam & 0 & \\
\hline Stillwater & P00078042+00391 & $45.59366 ; 109.29695$ & 1134 & $16 \mathrm{Jul}$ & steel & I-beam & 0 & \\
\hline Stillwater & P00078043+05911 & $45.61259 ; 109.28018$ & 1125 & $16 \mathrm{Jul}$ & wood & girder & 2 & $\begin{array}{l}\text { LACI (1) } \\
\text { EPFU (12) }\end{array}$ \\
\hline Stillwater & P00078046+01371 & $45.62819 ; 109.25580$ & 1101 & $16 \mathrm{Jul}$ & steel & I-beam & 0 & \\
\hline Stillwater & P00028094+03641 & $45.47511 ; 108.99780$ & 1166 & $16 \mathrm{Jul}$ & concrete & T-beam & 1 & $?$ \\
\hline Stillwater & $\mathrm{P} 00028084+03671$ & $45.38306 ; 109.14221$ & 1354 & $16 \mathrm{Jul}$ & concrete & T-beam & 1 & $?$ \\
\hline Stillwater & I00090408+09031 & $45.64661 ; 109.24789$ & 1111 & $17 \mathrm{Jul}$ & concrete & T-beam & 1 & $?$ \\
\hline Stillwater & I00090408+09032 & $45.64706 ; 109.24765$ & 1112 & $17 \mathrm{Jul}$ & concrete & T-beam & 1 & $?$ \\
\hline
\end{tabular}




\begin{tabular}{|c|c|c|c|c|c|c|c|c|}
\hline County & MDT Bridge No. & $\begin{array}{c}\text { GPS Lati-Long } \\
(\mathrm{N} ; \mathrm{W})\end{array}$ & $\begin{array}{l}\text { Elevation } \\
\text { (m) }\end{array}$ & Date & $\begin{array}{c}\text { Bridge } \\
\text { Material }\end{array}$ & $\begin{array}{l}\text { Bridge } \\
\text { Design }\end{array}$ & $\begin{array}{l}\text { Bat } \\
\text { Use }^{a}\end{array}$ & $\begin{array}{c}\text { Bat } \\
\text { Species }\end{array}$ \\
\hline Stillwater & S00306000+09691 & 45.64098; 109.27159 & 1109 & $17 \mathrm{Jul}$ & concrete & T-beam & 1 & $?$ \\
\hline Stillwater & S00306002+02901 & $45.65571 ; 109.27427$ & 1135 & $17 \mathrm{Jul}$ & concrete & T-beam & 2 & EPFU (8) \\
\hline Stillwater & S00306007+00351 & $45.71786 ; 109.29029$ & 1200 & $17 \mathrm{Jul}$ & steel & I-beam & 1 & $?$ \\
\hline Stillwater & S00420000+03001 & $45.52365 ; 109.44719$ & 1226 & $17 \mathrm{Jul}$ & concrete & T-beam & 1 & $?$ \\
\hline Stillwater & S00419000+01001 & $45.48050 ; 109.45345$ & 1291 & $17 \mathrm{Jul}$ & concrete & slab & 0 & \\
\hline Stillwater & S00419000+02001 & $45.48039 ; 109.45428$ & 1287 & $17 \mathrm{Jul}$ & concrete & slab & 0 & \\
\hline Stillwater & S00419003+05001 & $45.45344 ; 109.50645$ & 1351 & $17 \mathrm{Jul}$ & concrete & slab & 0 & \\
\hline Stillwater & S00419003+06001 & $45.45340 ; 109.50745$ & 1352 & $17 \mathrm{Jul}$ & concrete & slab & 0 & \\
\hline Stillwater & S00419006+08001 & $45.43894 ; 109.54958$ & 1393 & $17 \mathrm{Jul}$ & concrete & box-beam & 0 & \\
\hline Stillwater & S00419018+02001 & $45.43325 ; 109.76255$ & 1489 & $17 \mathrm{Jul}$ & concrete & slab & 0 & \\
\hline Stillwater & S00419019+09001 & $45.43547 ; 109.79691$ & 1467 & $17 \mathrm{Jul}$ & concrete & slab & 1 & $?$ \\
\hline Stillwater & S00419021+03001 & $45.44246 ; 109.80649$ & 1497 & $17 \mathrm{Jul}$ & wood & girder & 1 & $?$ \\
\hline Stillwater & S00419021+04001 & $45.44311 ; 109.80606$ & 1476 & $17 \mathrm{Jul}$ & steel & I-beam & 0 & \\
\hline Stillwater & I00090400+06311 & $45.70105 ; 109.38873$ & 1127 & $18 \mathrm{Jul}$ & concrete & T-beam & 1 & $?$ \\
\hline Stillwater & I00090400+06312 & $45.70075 ; 109.38861$ & 1127 & $18 \mathrm{Jul}$ & concrete & T-beam & 1 & $?$ \\
\hline Stillwater & L48115000+08001 & $45.68685 ; 109.43780$ & 1136 & $18 \mathrm{Jul}$ & steel & I-beam & 1 & $?$ \\
\hline Stillwater & I00090396+09921 & $45.68404 ; 109.45317$ & 1137 & $18 \mathrm{Jul}$ & concrete & T-beam & 0 & \\
\hline Stillwater & L48244007+08001 & $45.70058 ; 109.39390$ & 1138 & $18 \mathrm{Jul}$ & concrete & T-beam & 1 & $?$ \\
\hline Stillwater & I00090400+03661 & $45.70086 ; 109.39419$ & 1122 & $18 \mathrm{Jul}$ & concrete & T-beam & 2 & EPFU (1) \\
\hline Stillwater & I00090400+03662 & $45.70114 ; 109.39431$ & 1130 & $18 \mathrm{Jul}$ & concrete & T-beam & 1 & $?$ \\
\hline Stillwater & L48244008+04001 & $45.69788 ; 109.40632$ & 1133 & $18 \mathrm{Jul}$ & concrete & T-beam & 2 & EPFU (1) \\
\hline Stillwater & L48096000+01001 & $45.63029 ; 109.19993$ & 1161 & $18 \mathrm{Jul}$ & steel & I-beam & 1 & $?$ \\
\hline Stillwater & L48245004+04001 & $45.60837 ; 109.16976$ & 1080 & $18 \mathrm{Jul}$ & concrete & T-beam & 1 & $?$ \\
\hline Stillwater & L48245005+01001 & $45.60460 ; 109.15813$ & 1075 & $18 \mathrm{Jul}$ & steel & I-beam & 1 & $?$ \\
\hline Stillwater & I00090414+02351 & $45.60483 ; 109.15816$ & 1080 & $18 \mathrm{Jul}$ & concrete & T-beam & ${ }^{\mathrm{d}} 1$ & ${ }^{\mathrm{d}} ?$ \\
\hline Stillwater & I00090414+02352 & $45.60528 ; 109.15783$ & 1088 & $18 \mathrm{Jul}$ & concrete & T-beam & 2 & EPFU (4) \\
\hline Stillwater & L48245010+03001 & $45.59475 ; 109.05416$ & 1071 & $18 \mathrm{Jul}$ & steel & I-beam & 0 & \\
\hline Stillwater & I00090421+08101 & $45.61229 ; 109.00791$ & 1061 & $18 \mathrm{Jul}$ & concrete & T-beam & 1 & $?$ \\
\hline Stillwater & I00090421+08102 & $45.61259 ; 109.00792$ & 1059 & $18 \mathrm{Jul}$ & concrete & T-beam & 1 & $?$ \\
\hline Stillwater & L48245015+08001 & $45.62575 ; 108.95007$ & 1047 & $18 \mathrm{Jul}$ & steel & I-beam & 1 & $?$ \\
\hline
\end{tabular}




\begin{tabular}{|c|c|c|c|c|c|c|c|c|}
\hline County & MDT Bridge No. & $\begin{array}{c}\text { GPS Lati-Long } \\
(\mathrm{N} ; \mathrm{W})\end{array}$ & $\begin{array}{c}\text { Elevation } \\
(\mathrm{m})\end{array}$ & Date & $\begin{array}{c}\text { Bridge } \\
\text { Material }\end{array}$ & $\begin{array}{l}\text { Bridge } \\
\text { Design }\end{array}$ & $\begin{array}{l}\text { Bat } \\
\text { Use }^{\text {a }}\end{array}$ & $\begin{array}{c}\text { Bat } \\
\text { Species }\end{array}$ \\
\hline Stillwater & L48120000+02001 & $45.62653 ; 108.95031$ & 1047 & $18 \mathrm{Jul}$ & concrete & T-beam & 1 & $?$ \\
\hline Stillwater & I00090424+07551 & $45.62601 ; 108.95006$ & 1047 & $18 \mathrm{Jul}$ & concrete & T-beam & 1 & $?$ \\
\hline Stillwater & I00090424+07552 & $45.62628 ; 108.95017$ & 1046 & $18 \mathrm{Jul}$ & concrete & T-beam & 1 & $?$ \\
\hline Yellowstone & P00004052+06561 & $45.64343 ; 108.76041$ & 1053 & $16 \mathrm{Jul}$ & steel & I-beam & 0 & \\
\hline Yellowstone & P00004052+09001 & $45.64581 ; 108.75760$ & 1017 & $16 \mathrm{Jul}$ & wood & girder & 0 & \\
\hline Yellowstone & P00004053+05141 & $45.65364 ; 108.75923$ & 1015 & $16 \mathrm{Jul}$ & steel & I-beam & 1 & $?$ \\
\hline Yellowstone & I00090434+00902 & $45.66283 ; 108.76954$ & 1011 & $16 \mathrm{Jul}$ & concrete & T-beam & 0 & \\
\hline Yellowstone & I00090434+00901 & $45.66272 ; 108.76909$ & 1011 & $16 \mathrm{Jul}$ & concrete & T-beam & 0 & \\
\hline Yellowstone & P00004054+07361 & $45.66827 ; 108.77154$ & 1013 & $16 \mathrm{Jul}$ & steel & I-beam & 0 & \\
\hline Yellowstone & P00004057+07411 & $45.68274 ; 108.71438$ & 1004 & $16 \mathrm{Jul}$ & steel & I-beam & 0 & \\
\hline Yellowstone & I00090437+04792 & $45.68309 ; 108.70609$ & 996 & $16 \mathrm{Jul}$ & concrete & T-beam & 1 & $?$ \\
\hline Yellowstone & I00090437+04791 & $45.68311 ; 108.70602$ & 996 & $16 \mathrm{Jul}$ & concrete & T-beam & 1 & $?$ \\
\hline Yellowstone & P00016000+00001 & $45.79654 ; 108.45753$ & 966 & $17 \mathrm{Jul}$ & concrete & T-beam & 0 & \\
\hline Yellowstone & P00016000+04641 & $45.79628 ; 108.46568$ & 960 & $17 \mathrm{Jul}$ & steel & I-beam & 0 & \\
\hline Yellowstone & $\mathrm{P} 00016000+06721$ & $45.79669 ; 108.47072$ & 946 & $17 \mathrm{Jul}$ & concrete & T-beam & 2 & EPFU (2) \\
\hline Yellowstone & P00016005+01671 & $45.84784 ; 108.46607$ & 955 & $17 \mathrm{Jul}$ & concrete & T-beam & 1 & $?$ \\
\hline Yellowstone & P00016005+07311 & $45.85587 ; 108.46662$ & 974 & $17 \mathrm{Jul}$ & concrete & T-beam & 1 & $?$ \\
\hline Yellowstone & P00016024+07541 & $46.12675 ; 108.45808$ & 1039 & $17 \mathrm{Jul}$ & concrete & T-beam & 1 & $?$ \\
\hline Yellowstone & I00094006+02072 & $45.88430 ; 108.30849$ & 936 & $17 \mathrm{Jul}$ & concrete & T-beam & 0 & \\
\hline Yellowstone & I00094006+02071 & $45.88444 ; 108.30857$ & 935 & $17 \mathrm{Jul}$ & concrete & T-beam & 1 & $?$ \\
\hline Yellowstone & S00522000+02451 & $45.88729 ; 108.31152$ & 922 & $17 \mathrm{Jul}$ & concrete & T-beam & 1 & $?$ \\
\hline Yellowstone & S00522000+03681 & $45.88903 ; 108.31227$ & 919 & $17 \mathrm{Jul}$ & concrete & T-beam & 1 & $?$ \\
\hline Yellowstone & S00568000+00001 & $45.98656 ; 107.99017$ & 890 & $17 \mathrm{Jul}$ & steel & I-beam & 1 & $?$ \\
\hline Yellowstone & S00568000+00621 & $45.98814 ; 107.99321$ & 889 & $17 \mathrm{Jul}$ & steel & I-beam & 0 & \\
\hline Yellowstone & S00568001+09601 & $45.99606 ; 108.00970$ & 891 & $17 \mathrm{Jul}$ & concrete & T-beam & 1 & $?$ \\
\hline Yellowstone & L56788022+06001 & $45.96848 ; 108.13955$ & 905 & $18 \mathrm{Jul}$ & concrete & culvert & 0 & \\
\hline Yellowstone & L56788027+07001 & $45.99403 ; 107.94715$ & 879 & $18 \mathrm{Jul}$ & wood & girder & 0 & \\
\hline Yellowstone & L56788029+05001 & $46.00636 ; 107.91502$ & 885 & $18 \mathrm{Jul}$ & wood & girder & 2 & ${ }^{e}$ EPFU (1) \\
\hline Yellowstone & L56788031+00001 & $46.01615 ; 107.89077$ & 897 & $18 \mathrm{Jul}$ & wood & girder & 0 & \\
\hline Yellowstone & L56788033+04001 & $46.02639 ; 107.84123$ & 883 & $18 \mathrm{Jul}$ & wood & girder & 0 & \\
\hline
\end{tabular}




\begin{tabular}{|c|c|c|c|c|c|c|c|c|}
\hline County & MDT Bridge No. & $\begin{array}{c}\text { GPS Lati-Long } \\
(\mathrm{N} ; \mathrm{W})\end{array}$ & $\begin{array}{c}\text { Elevation } \\
(\mathrm{m})\end{array}$ & Date & $\begin{array}{c}\text { Bridge } \\
\text { Material }\end{array}$ & $\begin{array}{l}\text { Bridge } \\
\text { Design }\end{array}$ & $\begin{array}{l}\text { Bat } \\
\text { Use }^{\text {a }}\end{array}$ & $\begin{array}{c}\text { Bat } \\
\text { Species }^{b}\end{array}$ \\
\hline Yellowstone & L56788035+00001 & $46.03467 ; 107.81032$ & 870 & $18 \mathrm{Jul}$ & wood & girder & 2 & " \\
\hline Yellowstone & L56788036+05001 & $46.04787 ; 107.78571$ & 865 & $18 \mathrm{Jul}$ & wood & girder & 2 & EPFU (32) \\
\hline Yellowstone & L56788039+03001 & $46.05970 ; 107.73238$ & 861 & $18 \mathrm{Jul}$ & steel & I-beam & 0 & \\
\hline Yellowstone & I00094047+02182 & $46.13079 ; 107.55399$ & 843 & $18 \mathrm{Jul}$ & concrete & T-beam & 1 & $?$ \\
\hline Yellowstone & I00094047+02181 & $46.13074 ; 107.55405$ & 841 & $18 \mathrm{Jul}$ & concrete & T-beam & 1 & $?$ \\
\hline Yellowstone & S00310000+08501 & $46.14122 ; 107.54980$ & 830 & $18 \mathrm{Jul}$ & steel & I-beam & 1 & $?$ \\
\hline Yellowstone & L56104002+05001 & $46.14757 ; 107.46705$ & 827 & $18 \mathrm{Jul}$ & concrete & box-beam & 1 & $?$ \\
\hline Yellowstone & L56788012+07001 & $45.90416 ; 108.32114$ & 876 & $18 \mathrm{Jul}$ & steel & I-beam & 0 & \\
\hline Yellowstone & I00094036+00311 & $46.05326 ; 107.75208$ & 856 & $19 \mathrm{Jul}$ & concrete & T-beam & 1 & $?$ \\
\hline Yellowstone & I00094036+00312 & $46.05357 ; 107.75222$ & 859 & $19 \mathrm{Jul}$ & concrete & T-beam & 1 & $?$ \\
\hline Yellowstone & L56788010+03001 & $45.90153 ; 108.36391$ & 946 & $19 \mathrm{Jul}$ & wood & girder & 2 & EPFU (1) \\
\hline Yellowstone & L56788006+05001 & $45.87162 ; 108.42485$ & 963 & $19 \mathrm{Jul}$ & wood & girder & 0 & \\
\hline Yellowstone & L56788004+03001 & $45.84843 ; 108.45788$ & 960 & $19 \mathrm{Jul}$ & wood & girder & 0 & \\
\hline Yellowstone & S00532005+09881 & $45.77392 ; 108.79642$ & 1053 & 19 Aug & concrete & T-beam & 1 & $?$ \\
\hline Yellowstone & S00532007+03001 & $45.76960 ; 108.77589$ & 1047 & 19 Aug & wood & girder & 0 & \\
\hline Yellowstone & S00532009+03001 & $45.76485 ; 108.74104$ & 1041 & 19 Aug & wood & girder & 0 & \\
\hline Yellowstone & S00532009+06001 & $45.75986 ; 108.74109$ & 1026 & 19 Aug & concrete & slab & 1 & $?$ \\
\hline Yellowstone & S00532010+06381 & $45.75521 ; 108.72693$ & 1026 & 19 Aug & concrete & box-beam & 2 & MYLU (11) \\
\hline Yellowstone & S00532011+08781 & $45.75504 ; 108.69810$ & 1025 & $19 \mathrm{Aug}$ & wood & girder & 0 & \\
\hline Yellowstone & S00416000+03691 & $45.73589 ; 108.53378$ & 967 & 19 Aug & steel & I-beam & 1 & $?$ \\
\hline Yellowstone & S00416000+09591 & $45.72728 ; 108.53288$ & 937 & 19 Aug & concrete & T-beam & 1 & $?$ \\
\hline Yellowstone & L56791008+06001 & $45.71529 ; 108.31409$ & 1013 & 20 Aug & concrete & T-beam & 1 & $?$ \\
\hline Yellowstone & L56791009+00001 & $45.71283 ; 108.30908$ & 1020 & 20 Aug & steel & I-beam & 1 & $?$ \\
\hline Yellowstone & I00090469+07532 & $45.77881 ; 108.14081$ & 1208 & 20 Aug & concrete & T-beam & 1 & $?$ \\
\hline Yellowstone & I00090469+07531 & $45.77843 ; 108.14077$ & 1211 & 20 Aug & concrete & T-beam & 1 & $?$ \\
\hline Yellowstone & L56271000+00001 & $45.79902 ; 108.28915$ & 994 & 20 Aug & steel & I-beam & 0 & \\
\hline Yellowstone & I00090455+03082 & $45.81539 ; 108.41393$ & 962 & 20 Aug & concrete & T-beam & 0 & \\
\hline Yellowstone & I00090455+03081 & $45.81500 ; 108.41412$ & 962 & 20 Aug & concrete & T-beam & 0 & \\
\hline Yellowstone & I00094006+02071 & $45.88439 ; 108.30825$ & 939 & $20 \mathrm{Aug}$ & concrete & T-beam & 1 & $?$ \\
\hline Yellowstone & I00094006+02072 & $45.88453 ; 108.30849$ & 940 & 20 Aug & concrete & T-beam & 1 & $?$ \\
\hline
\end{tabular}




\begin{tabular}{|c|c|c|c|c|c|c|c|c|}
\hline County & MDT Bridge No. & $\begin{array}{c}\text { GPS Lati-Long } \\
(\mathrm{N} ; \mathrm{W})\end{array}$ & $\begin{array}{c}\text { Elevation } \\
(\mathrm{m})\end{array}$ & Date & $\begin{array}{c}\text { Bridge } \\
\text { Material }\end{array}$ & $\begin{array}{l}\text { Bridge } \\
\text { Design }\end{array}$ & $\begin{array}{l}\text { Bat } \\
\text { Use }^{a}\end{array}$ & $\begin{array}{c}\text { Bat } \\
\text { Species }\end{array}$ \\
\hline Yellowstone & I00094014+08431 & 45.93918; 108.14896 & 967 & $20 \mathrm{Aug}$ & concrete & T-beam & 0 & \\
\hline Yellowstone & I00094014+08432 & $45.93971 ; 108.14896$ & 967 & $20 \mathrm{Aug}$ & concrete & T-beam & 1 & $?$ \\
\hline Yellowstone & S00568000+00001 & $45.98685 ; 107.99043$ & 898 & $20 \mathrm{Aug}$ & steel & I-beam & 0 & \\
\hline Yellowstone & $\mathrm{I} 00094025+01201$ & $45.99296 ; 107.95305$ & 904 & $20 \mathrm{Aug}$ & concrete & T-beam & 1 & $?$ \\
\hline Yellowstone & I00094025+01202 & $45.99265 ; 107.95292$ & 892 & $20 \mathrm{Aug}$ & concrete & T-beam & 1 & $?$ \\
\hline Yellowstone & I00094025+05971 & $45.99364 ; 107.94693$ & 876 & 20 Aug & concrete & slab & 0 & \\
\hline Yellowstone & I00094025+05972 & $45.99337 ; 107.94961$ & 876 & $20 \mathrm{Aug}$ & concrete & slab & 0 & \\
\hline Yellowstone & I00094034+02451 & $46.04636 ; 107.78749$ & 871 & $20 \mathrm{Aug}$ & concrete & slab & 0 & \\
\hline Yellowstone & I00094034+02452 & $46.04612 ; 107.78725$ & 870 & 20 Aug & concrete & slab & 1 & $?$ \\
\hline Yellowstone & I00094029+07771 & $46.00302 ; 107.91053$ & 880 & $20 \mathrm{Aug}$ & concrete & T-beam & 1 & $?$ \\
\hline Yellowstone & I00094029+07771 & $46.00253 ; 107.91048$ & 880 & $20 \mathrm{Aug}$ & concrete & T-beam & 1 & $?$ \\
\hline Yellowstone & I00094030+07921 & $46.01456 ; 107.86339$ & 900 & $20 \mathrm{Aug}$ & concrete & slab & 0 & \\
\hline Yellowstone & I00094030+07922 & $46.01411 ; 107.86328$ & 901 & $20 \mathrm{Aug}$ & concrete & slab & 1 & $?$ \\
\hline
\end{tabular}

${ }^{\mathrm{a}} 0=$ no use, 1 = night roost, 2 = day roost.

${ }^{\mathrm{b}}$ EPFU: Eptesicus fuscus (Big Brown Bat), LACI: Lasiurus cinereus (Hoary Bat), MYLU: Myotis lucifugus (Little Brown Myotis), ?: species unknown.

${ }^{\mathrm{c}}$ Individual was probably sick; no bats were present during the day on additional visits.

${ }^{\mathrm{d}}$ Structure used as a day roost by EPFU on later visits (see Table 1).

${ }^{\mathrm{e}}$ Structure used as a day roost by Western Small-footed Myotis (Myotis ciliolabrum) on later visits (see Table 1). 
175 copies of this public document were produced at an estimated cost of 1.50 each, for a total cost of $\$ 263.00$. This includes $\$ 129.00$ for postage and $\$ 134.00$ for printing. 